\title{
Corrosion characteristics of cold gas spray coatings of reinforced aluminum deposited onto carbon steel
}

\author{
F.S.da Silva ${ }^{\mathrm{a}, \mathrm{b}}$, J. Bedoya $^{\mathrm{b}}$, S. Dosta ${ }^{\mathrm{b}}$, N. Cinca ${ }^{\mathrm{b}}$, I.G. Cano $^{\mathrm{b}}$, J.M. Guilemany $^{\mathrm{b}}$, \\ A.V. Benedetti ${ }^{a, *}$ \\ a Instituto de Química, UNESP - Univ Estadual Paulista, Departamento de Físico-Química, Rua Prof. Francisco Degni, 55, 14800-060, P. O. Box 355, \\ Araraquara, SP, Brazil \\ b Barcelona University, CPT, Martí I Franqués 1, 08028 Barcelona, Spain
}

\section{A R T I C L E I N F O}

\section{Article history:}

Received 17 June 2016

Received in revised form 20 October 2016

Accepted 21 October 2016

Available online 24 October 2016

\section{Keywords:}

Aluminum

Metal coatings

EIS

Polarization

SEM

XRD

\begin{abstract}
A B S T R A C T
The morphology, chemical, mechanical and corrosion characterization of starting materials, and $\mathrm{Al}$ and $\mathrm{Al}-\mathrm{Al}_{2} \mathrm{O}_{3} / \mathrm{Al}$ coatings obtained by Cold Gas Spray and applied on common steel substrate were performed. An Al coating on a ground or grit blasted substrate, and $\mathrm{Al}_{-}-\mathrm{Al}_{2} \mathrm{O}_{3} / \mathrm{Al}$ coating on ground mild carbon steel have been compared. The electrochemical results showed that the coatings protect the substrate for immersion times $>2000 \mathrm{~h}$ due to the dense structure obtained by $\mathrm{Al}$ and $\mathrm{Al}^{-} \mathrm{Al}_{2} \mathrm{O}_{3}$. The electrolyte reaches the substrate only after $2000 \mathrm{~h}$ of immersion without wetting completely the coating/substrate interface. Coatings have resisted $3000 \mathrm{~h}$ of salt fog test.
\end{abstract}

(c) 2016 Elsevier Ltd. All rights reserved.

\section{Introduction}

Cold gas spray has emerged in the field of surface engineering as a new process of high performance and low cost to obtain coatings with large thickness $(0.2-25 \mathrm{~mm})$, good adhesion and high performance unattainable by conventional thermal spray technologies. The underlying principle of cold spraying is that the sprayed material is no longer heated, semi-molten or fully molten to be stuck on surface substrate. Instead, solid state powders are accelerated in a high pressure supersonic gas jet (in a nozzle with convergent-divergent geometry) that allows the particles to be plastically deformed during impact with the target to form interconnected splats adhered to the substrate, resulting an overlay deposit [1]. When the particle velocity exceeds a certain critical value, the energy of impact on the substrate causes an intense plastic deformation of the particle and, in some cases, of the substrate surface [1,2]. This allows obtaining very dense coatings without oxidation or diffusion into the substrate, because the sprayed material does not melt [3-8].

Unlike other spraying techniques, CGS uses the kinetic energy instead of heat energy to the deposition [2]. Thus residual ten-

\footnotetext{
* Corresponding author.

E-mail address: benedeti@iq.unesp.br (A.V. Benedetti).
}

sile stresses, oxidation and unwanted chemical reactions can be avoided [2,9-12]. In CGS the working temperature is lower than that used in other spraying techniques and does not exceed $1000^{\circ} \mathrm{C}$, but the speed during spraying can reach, depending on the used gas or spray parameters, between 500 and $1200 \mathrm{~m} / \mathrm{s}$ [13,14]. These features make the CGS an important technique to obtain Al-based coatings since it is sensitive to oxidation and has mechanical properties that promote plastic deformation of the particles.

Aluminum coatings have been a good alternative for the corrosion protection of components [15], however the wear resistance of these coatings must be improved.

In the last decades, studies have shown that the inclusion of ceramic particles as reinforcement can improve the mechanical properties [16-19]. Aluminum-matrix composites (AMCs) reinforced with particles and whiskers are widely used for high performance applications such as in automotive, military, aerospace and electricity industries because of their improved physical and mechanical properties [20]. Among the ceramic reinforced materials, $\mathrm{SiC}$ is the most common used in metallic-matrix composites (MMCs). The second most used reinforcement is $\mathrm{Al}_{2} \mathrm{O}_{3}$; when compared with $\mathrm{SiC}$, it is more stable and inert, and has better corrosion and high temperature resistance [21].

With the aim to improve corrosion and mechanical properties, the obtaining of such composite coatings are useful. Several investigations have been developed in the last years using different 
thermal spray techniques for this purpose: plasma-sprayed Al$\mathrm{Al}_{2} \mathrm{O}_{3}$ composite coatings [22]; cold gas spray $\mathrm{Al}-\mathrm{Al}_{2} \mathrm{O}_{3}$ composite coatings [23-25]. Cold gas spray technique was also used to prepare atomized Al-based coatings [9,26,27], and pure $\mathrm{Al}[7,14,28,29]$.

The comparison of $\mathrm{Al}$ coatings with composites of $\mathrm{Al}-\mathrm{Al}_{2} \mathrm{O}_{3}$ with $7,10,20,30,50$, and $75 \% \mathrm{Al}_{2} \mathrm{O}_{3}$ showed that the proportion of $70 \% \mathrm{Al} / 30 \% \mathrm{Al}_{2} \mathrm{O}_{3}$ provides better tribological properties and good corrosion resistance [23], which was also observed by [25]. The coating deposited on the etched substrate with $\mathrm{Al}_{2} \mathrm{O}_{3}$ had higher adhesion reaching $42 \mathrm{MPa}$. Other studies have also reported good adhesion of aluminum coatings, dense microstructure and low porosity when deposited by CGS [26,29].

Some studies have evaluated the corrosion resistance of $\mathrm{Al}$ and $\mathrm{Al}-\mathrm{Al}_{2} \mathrm{O}_{3}$ coatings by means of electrochemical measurements $[1,14,23,24,28]$. The corrosion resistance of $\mathrm{Al}$ coatings, deposited on the AZ91D magnesium alloy, in $3.5 \% \mathrm{NaCl}$ solution measured using EIS showed: (a) within the first $24 \mathrm{~h}$, the coating resistance decreased and the capacitance and the diffusion impedance increased due to the pitting process that forms pores, which are filled with corrosion products and solution; from $48 \mathrm{~h}$ to $250 \mathrm{~h}$ the capacitance and resistance of the coating become virtually unchanged because the areas between the splats of Al became occupied by corrosion products [28]. EIS and SEM studies of Al coatings on steel showed absence of corrosion of the substrate even after $720 \mathrm{~h}$ in $3.5 \% \mathrm{NaCl}$, and that CPE (constant phase element) and resistance of the coating fluctuate in the early hours of immersion due to localized corrosion, followed by a stabilization up to $500 \mathrm{~h}$ of immersion, which was attributed to the accumulation of corrosion products on the active areas of the coating [14]. Studies of 75Al$25 \mathrm{Al}_{2} \mathrm{O}_{3} /$ steel coatings, using potentiodynamic polarization, have concluded that the corrosion current densities of the composite coatings were of the same order as that of the pure Al coating, and the corrosion potentials were more positives [25]. Similar behavior was also observed for the pure Al- and AA6061 Al alloy-based $\mathrm{Al}_{2} \mathrm{O}_{3}$ particle reinforced composite coatings deposited on AZ91E substrates [19]. However, none of these studies investigated a coating deposited by CGS, and mainly consisting of a bilayer: a top layer of $\mathrm{Al}-\mathrm{Al}_{2} \mathrm{O}_{3}$ composite and a bottom layer of atomized $\mathrm{Al}$ powder on steel ( $\mathrm{Al}-\mathrm{Al}_{2} \mathrm{O}_{3} / \mathrm{Al} /$ steel substrate), and to the authors' knowledge, this is the first report comparing a bilayer $\mathrm{Al}_{-} \mathrm{Al}_{2} \mathrm{O}_{3} / \mathrm{Al} /$ steel composite coating with $\mathrm{Al} /$ steel coating deposited on the same substrate. Therefore, more investigations on the performance of composite coatings are required to clarify the situation and to gain an understanding of the underlying mechanism.

The objective of this work is to study the deposition of aluminum onto carbon steel to protect against corrosion and to assess the feasibility of adding $\mathrm{Al}_{2} \mathrm{O}_{3}$ reinforcing in order to improve wear resistance, maintaining the corrosion resistance of $\mathrm{Al}$. In contrast to investigations reported by other researchers, the reinforcing $\mathrm{Al}_{2} \mathrm{O}_{3}$ particles (to make $\mathrm{Al}-\mathrm{Al}_{2} \mathrm{O}_{3}$ composite) were deposited on the top layer of an Al coating. The main reason is to guarantee better mechanical resistance on the surface with good corrosion resistance gave by the pure aluminum at the bottom. For this purpose, $\mathrm{Al}$ and $\mathrm{Al}_{2} \mathrm{O}_{3}$ powders were simultaneously sprayed from different powder feeds. Besides the optimization of the depositing parameters, morphological, chemical, mechanical, and electrochemical characterization were performed to assess structural, tribological, and corrosion resistance properties.

\section{Experimental}

\subsection{Feedstock materials}

The powders used as feedstock were commercially available gas-atomized aluminum (TLS Technik GmbH, Germany) 99.7\% (according to manufacturer) and commercially available $\mathrm{Al}_{2} \mathrm{O}_{3}$ (MPA, Spain) particles used as reinforcement on the top layer of some of the coatings evaluated. Fig. 1 shows the SEM micrographs of the free surface of the $\mathrm{Al}$ powder and $\mathrm{Al}_{2} \mathrm{O}_{3}$ particles. The $\mathrm{Al}$ powder shows a rounded morphology, not completely spherical (Fig. 1(a)), particle size is ranged from 5 to $80 \mu \mathrm{m}$, with a mean particle size of $28 \mu \mathrm{m}$ (Fig. $1 \mathrm{~S}(\mathrm{a})$, Supplementary data). $\mathrm{Al}_{2} \mathrm{O}_{3}$ particles have an angular morphology (Fig. 1(b)) with size ranged from 20 to $180 \mu \mathrm{m}$ and a mean particle size of $63 \mu \mathrm{m}$ (Fig. 1S(b), Supplementary data). The powder composition was evaluated through XRD and EDS analysis, and only pure aluminum and $\alpha-\mathrm{Al}_{2} \mathrm{O}_{3}$ were detected. The oxygen content in $\mathrm{Al}$ powder was less than $3 \mathrm{wt} \%$ according to the EDS analysis.

\subsection{Substrate and reactants}

A low carbon steel alloy with the composition $\mathrm{Al}$ (0.46 wt\%), Tl (0.22 wt\%), Mn (0.18wt\%), C (0.15 wt\%), Cr (0.091 wt\%), Zn (0.080 wt\%) and Fe balance, determined using an EDX-720/800HS Energy Dispersive X-ray Fluorescence Spectrometer, SHIMADZU, was used as substrate. The rectangular and flat substrates $(50 \mathrm{~mm} \times 20 \mathrm{~mm} \times 5 \mathrm{~mm})$ and cylindrical $(\phi=25.4 \mathrm{~mm}$ and $\mathrm{h}=25.4 \mathrm{~mm}$ ) were degreased with acetone and surface ground with P240 SiC paper, which gave a surface roughness $\left(R_{\mathrm{a}}\right)$ of $\sim 0.5 \mu \mathrm{m}$ or grit blasting with alumina (MPA, Spain) 220 -grade corundum using a low pressure cold gas spray (LPCGS) system, leading to a $R_{\mathrm{a}}=4.7 \pm 0.4 \mu \mathrm{m}$. Using different roughness for the same substrate the particles sprayed can be better accommodated on the surface that may improve the mechanical interaction at the coating/substrate interface. The surface roughness was the average of at least ten roughness measures on each sample surface. The measures were performed using a Mitutuyo Surftest 301 Precision reference specimen calibrated with a calibrator $2.97 \mu \mathrm{m}$ rough. Some corundum residue was observed when grit blasting was performed by the cold gas spray system, caused by the high velocity of corundum particles [27]. The surface roughness of the substrates pre-treated with grinding or grit blasting were measured with MITUTOYO Surftest-301 equipment.

$\mathrm{NaCl}$ (Sigma Aldrich) 99.8\% was used as supporting electrolyte without previous purification, and Milli-Q water $(18.2 \mathrm{M} \Omega \mathrm{cm})$ for preparing the solutions for corrosion testing. The Keller's reactive ( $2 \mathrm{ml} \mathrm{HF}, 3 \mathrm{ml} \mathrm{HCl}, 5 \mathrm{ml} \mathrm{HNO}_{3}$ and $190 \mathrm{ml} \mathrm{H}_{2} \mathrm{O}$,) was used for etching the $\mathrm{Al}$ coating cross section surface.

\subsection{Coating preparation}

Aluminum coatings were obtained and optimized in the Thermal Spray Centre, Barcelona, using a KINETICS 4000 CGT (Cold Gas Technology $\mathrm{GmbH}$ ), capable of reaching 40 bar pressure and $800^{\circ} \mathrm{C}$ using $\mathrm{N}_{2}$ as streaming gas. A polymeric nozzle (type 33 ) was used to deposit the aluminum coatings. CGS parameters were optimized to improve efficiency and adhesion without grit blasting the substrate surface. Pressure was tested from 10 to 35 bar and temperature from $200^{\circ} \mathrm{C}$ to $400^{\circ} \mathrm{C}$. Other parameters such as spraying distance, nozzle transverse speed, feed rate and spray angle were kept constant. Coatings obtained at high pressure and low temperatures have shown very low deposition efficiency, high porosity, and poor cohesion between particles and at the interface. These coatings showed thicknesses not exceeding $100 \mu \mathrm{m}$. The optimized parameters were $25 \mathrm{bar}$, temperature of $350^{\circ} \mathrm{C}$, traversing velocity of $500 \mathrm{~mm} / \mathrm{s}$, distance from the substrate $40 \mathrm{~mm}$ and deposition of 5 layers with $1 \mathrm{~mm}$ step size, resulting a nominal coating thickness of around $500 \mu \mathrm{m}$ (considering $100 \%$ of efficiency) [27].

Al powder and $\mathrm{Al}_{2} \mathrm{O}_{3}$ particles were simultaneously sprayed from different powder feeds, using the optimized parameters gave above. The feed ratio was 3:1 $\mathrm{Al}: \mathrm{Al}_{2} \mathrm{O}_{3}$. According to our know- 

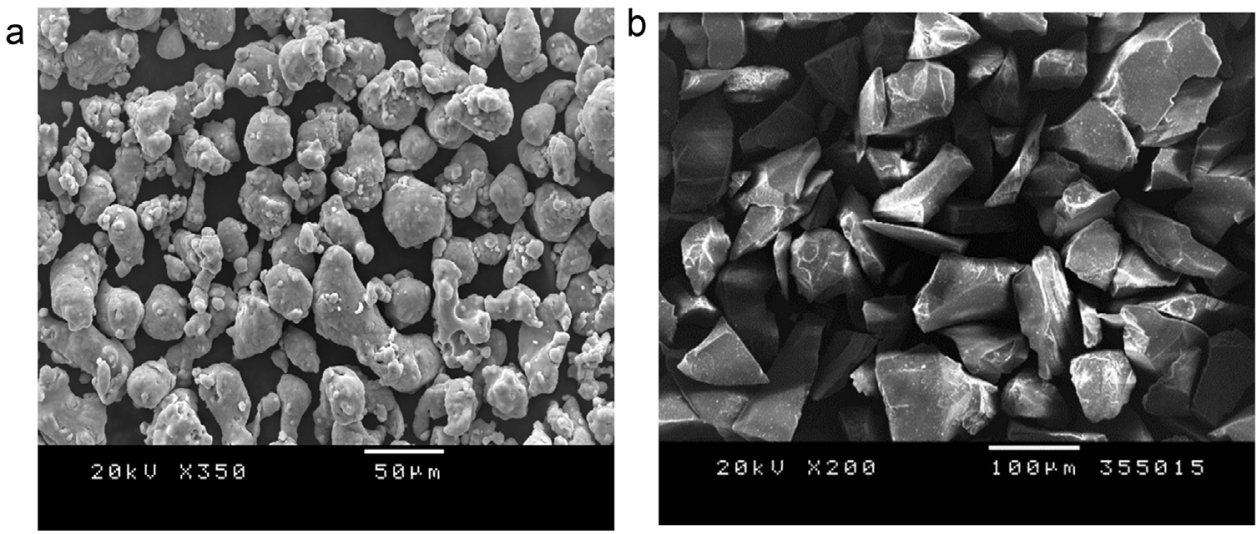

Fig. 1. SEM images of the powders: (a) aluminum and (b) $\alpha-\mathrm{Al}_{2} \mathrm{O}_{3}$.

how and also previous studies [23] a good balance between wear and corrosion resistance is obtained between 10 and $30 \%$ of $\mathrm{Al}_{2} \mathrm{O}_{3}$. That is why we considered this composition. First $\mathrm{Al}$ powder was deposited on steel, and then the composite $\mathrm{Al}-\mathrm{Al}_{2} \mathrm{O}_{3}$ was deposited on the $\mathrm{Al}$ layer, giving a bilayer coating: $\mathrm{Al}_{-} \mathrm{Al}_{2} \mathrm{O}_{3} / \mathrm{Al} /$ ground steel.

\subsection{Structural, morphological, chemical and mechanical characterization}

Powder and coatings have been structurally characterized by scanning electron microscopy (SEM) using a JEOL JSM-5310 scanning electron microscope coupled to an X-ray energy dispersive microanalysis (EDS) system or a Field Emission Electron Microscope (FEG) JSM - 7500F with an EDS Scientific Noran System six. SEM images were obtained at different $\mathrm{kV}$ energy values like was indicated in the corresponding figures. The coatings were analyzed by X-ray diffraction (XRD) using an X-ray diffractometer, SIEMENS model D5000. The total coating thickness and the thickness of the layer with alumina were determined in the transverse section from digital optical micrographs (OM) using the MATROX INSPECTOR Image Analysis (Matrox, Dorval, Canada) or Image J software. Aluminum-based coatings were also examined by OM after revealing the surface (cross section) with the Keller's reagent. Tensile strength was evaluated on the basis of the ASTM C-633 Standard Practice and microhardness by means of a Matsuzawa MTX- $\alpha$ (Japan) Vickers apparatus, following the ASTM E384-99 Standard Practice. The mean values were obtained from at least 20 indentations performed at a load of $100 \mathrm{gf}$ on the polished cross sections of the coatings.

The tribological properties of these coatings were characterized by two standardized wear tests. The sliding wear test was carried out using a Ball-on-Disk (BOD) method (ASTM G99-04 Standard Practice) to evaluate the friction coefficient and the Rubber-Wheel (RW) test (ASTMG65-00 Standard Practice) was used to evaluate the abrasive coefficient. For both tests, the initial surfaces were polished until a roughness $R_{a}$ between 0.45 and $0.50 \mu \mathrm{m}$, being that for $\mathrm{Al}-\mathrm{Al}_{2} \mathrm{O}_{3} / \mathrm{Al}$ near $0.5 \mu \mathrm{m}$.

The BOD was carried using a CM4 Ball-on-Disk instrument at $25^{\circ} \mathrm{C}$, steel balls $14 \mathrm{~mm}$ in diameter and a hardness of HVN300 $=1700$ as counterparts, a sample relative velocity of 131 $\mathrm{rpm}$, a total test length of $900 \mathrm{~m}$, a sliding speed of $0.029 \mathrm{~m} / \mathrm{s}$, and $5 \mathrm{~N}$ of load vertically applied. The friction force was recorded during the test. The friction energy was calculated as the area under the friction force versus the accumulated sliding distance. Friction coefficients were calculated from the average value measured in the last $200 \mathrm{~m}$. The wear tracks produced on the coatings were studied using SEM. A Leica DCM3D confocal equipment with Sensoscan or
Mountain LeicaScan software was used to measure the volume loss of the wear tracks and to recreate the wear path.

Dry abrasive tests were carried out using a CM4 Rubber Wheel (RW) machine with a rotation rate of $139 \mathrm{rpm}$, a load of $50 \mathrm{~N}$ with a flow of silica $\left(\phi=0.4\right.$ to $0.8 \mathrm{~mm}$ ) between 250 and $310 \mathrm{~g} \mathrm{~min}^{-1}$. Material loss was measured by weighing the samples every $1 \mathrm{~min}$ during the first $5 \mathrm{~min}$ and then every $5 \mathrm{~min}$ until the end of the test (duration of the test $30 \mathrm{~min}$ ). To express the wear rate in terms of the material removed, the density of the coatings was used to transform mass in volume.

\subsection{Corrosion studies}

All the experiments were carried out using a conventional Tait type three-electrode electrochemical cell with $80 \mathrm{ml}$ electrolyte solution. The substrates (ground with P240 SiC paper) or asprepared coated substrates were used as working electrodes, and were fixed at the bottom of the electrochemical cell. The counter electrode was a Pt grid, and the potentials were referred to an aqueous $\mathrm{Ag}|\mathrm{AgCl}| \mathrm{KCl} 3 \mathrm{~mol} / \mathrm{l}$ reference electrode connected to the working solution through a Luggin capillary. The electrolyte was a non-deaerated and unstirred $3.5 \mathrm{wt} \% \mathrm{NaCl}$ aqueous solution at $(25 \pm 1)^{\circ} \mathrm{C}$.

The corrosion resistance of the coated samples was evaluated in the electrolyte by open circuit potential $\left(E_{\mathrm{OCP}}\right)$ measurements, small amplitude linear polarization (SALP), cyclic polarization (CP) and electrochemical impedance spectroscopy (EIS). Using SALP, $R_{\mathrm{p}}$ was determined from I-E curves by applying $\pm 10 \mathrm{mV} / E_{\mathrm{OCP}}$ and recorded at $0.166 \mathrm{mV} / \mathrm{s}$ after $18 \mathrm{~h}$ of immersion. Cyclic polarization experiments were performed after $18 \mathrm{~h}$ of $E_{\mathrm{OCP}}$, using a scan rate of $0.166 \mathrm{mV} / \mathrm{s}$ beginning at -0.100 to $+0.300 \mathrm{~V} / E_{\mathrm{OCP}}$, and the potential was reversed and scanning to $-0.250 \mathrm{~V} / E_{\mathrm{OCP}}$ (the final potential), and these curves were also used to obtain $i_{\text {corr }}$ values. The SternGeary equation was used to obtain the corresponding $R_{\mathrm{p}}$ values from $i_{\text {corr }}$ and the Tafel slopes $b_{\mathrm{a}}$ and $b_{\mathrm{c}}[30,31]$. EIS and $E_{\mathrm{OCP}}$ were monitored for relatively long immersion times: (a) $\mathrm{Al}$ on ground steel $700 \mathrm{~h}$; (b) Al on grit blasted steel $2200 \mathrm{~h}$; (c) $\mathrm{Al}-\mathrm{Al}_{2} \mathrm{O}_{3} / \mathrm{Al}$ coating on ground steel $650 \mathrm{~h}$, and (e) the steel substrate for $96 \mathrm{~h}$ of immersion. EIS measurements for coated samples were performed at $1 \mathrm{~h}$ and every $24 \mathrm{~h}$ of immersion, in the frequency range from $100 \mathrm{kHz}$ to $5 \mathrm{mHz}$, by applying a sinusoidal potential perturbation of $10 \mathrm{mV}$ rms on $E_{\mathrm{OCP}}$ with 10 points/frequency decade. All experimental data were tested for consistency with the Kramers-Kronig transform (KKT) available in the GAMRY system software, and only those points passing the test are presented and discussed in the paper. The Electrical Equivalent Circuit (EEC) theory using the Zview $^{\circledR}$ program was employed for quantitative analysis of the EIS responses. All measurements were done using Gamry Reference 
600 system, in non-deaerated and quiescent $3.5 \% \mathrm{NaCl}$ solution at $(25 \pm 1)^{\circ} \mathrm{C}$.

Salt spray tests of as-deposited $\mathrm{Al}$ coatings and $\mathrm{Al}-\mathrm{Al}_{2} \mathrm{O}_{3} / \mathrm{Al}$ coatings were performed with a Dycometal SSC-400 Salt Spray Cabinet in a neutral mist $5 \mathrm{wt} \% \mathrm{NaCl}$ at $35^{\circ} \mathrm{C}$ for $1000 \mathrm{~h}$, in accordance with ASTM B117-11 Standard Practice. As no signals of corrosion of the substrate were observed up to $1000 \mathrm{~h}$, time established by the Standard Practice, the salt spray test was continued for a total of $3000 \mathrm{~h}$.

\section{Results and discussion}

\subsection{Structural, morphological, chemical characterization}

Fig. 2 shows SEM and OM cross sections micrographs of $\mathrm{Al}$ coatings obtained with optimized conditions. OM micrograph was obtained after revealing the microstructure with Keller's reagent. Fig. 2(c) and (d) shows, respectively, the SEM and OM micrographs cross sections of reinforced coatings by introducing $\alpha-\mathrm{Al}_{2} \mathrm{O}_{3}$ into the last layer to improve wear resistance of the coating and maintaining the corrosion resistance.

Fig. 2(a) shows that Al particles are plastically deformed on impact yielding better bonding between particles and substrate, particles each other [2,32], and metallic oxides, cracks and interconnected porosity are not observed at the interface or along all the coating thickness. The porosity was lower than $0.8 \%$ (see Table $1 \mathrm{~S}$, Supplementary data), therefore, the Al coating can be considered compact. The etching of the cross section surface (Fig. 2(b)) shows deformed particles, and reveals the particles boundaries, but the boundaries between layers are not clearly seen.

The success in the optimization of spraying parameters to produce a compact Al coating with very low porosity and high corrosion resistance, encouraged us to reinforce this coating by adding alumina particles in the top layer (Fig. 2(c)), thus improving the mechanical properties without losing the corrosion resistance. Fig. 2(d) shows the optical micrograph of the top layer region, which is formed by the $\mathrm{Al}-\mathrm{Al}_{2} \mathrm{O}_{3}$ composite with the irregular shape alumina particles scattered through the aluminum matrix. It can be seen that $\mathrm{Al}_{2} \mathrm{O}_{3}$ particles, in this layer, are distributed throughout the Al matrix, which suggests that under the spray conditions used the two materials did not separate in the gas flow stream. The $\mathrm{Al}_{2} \mathrm{O}_{3}$ particles have irregular shape and average size of $40 \mu \mathrm{m}$, which is lower than the size of starting material, suggesting that at least part of the particles may have been broken with the impact. Some alumina particles are also surrounded by a halo of very small particles and according to [33], it could be formed by shattering of the highly accelerated particles on impact. A well-defined and wellconnected interface between $\mathrm{Al}$ and $\mathrm{Al}-\mathrm{Al}_{2} \mathrm{O}_{3}$ layers is seen, which indicates that diffusion is not a mechanism involved in this process due to the aluminum particles are not melted in CGS technology. The interface between the coating and the substrate follows the surface profile of the substrate, and no mutual penetration is observed on a macroscopic scale. Both coatings were also examined at higher magnifications.

A closer viewing of cross sections of the coatings shows two layers: an outer layer with higher porosity and defects, and an inner layer with fewer defects and more compact. Thus, Fig. 2S(a) (Supplementary data) shows the Al coating where one can see a less compact layer at the top and Fig. 2S(b) (Supplementary data) shows defects around some alumina particles. It is important to note that the porosity observed mainly on the top surface of the $\mathrm{Al}-\mathrm{Al}_{2} \mathrm{O}_{3} / \mathrm{Al}$ coating is not the overall porosity of the deposit, since part of them is closed by the next oncoming particles. For the surface of as-sprayed coatings, the roughness was greater than for the substrate, and the top layer less compact than the bottom layer. These results agree with $[34,35]$ that have described the CGS coat-
Table 1

Thickness of $\mathrm{Al}$ and $\mathrm{Al} / \mathrm{Al}-\mathrm{Al}_{2} \mathrm{O}_{3}$ coatings obtained by Gas Cold Spray.

\begin{tabular}{|c|c|c|c|}
\hline Sample & $\mathrm{Al} /$ ground steel ${ }^{\mathrm{a}}$ & $\begin{array}{l}\mathrm{Al} / \mathrm{Al}-\mathrm{Al}_{2} \mathrm{O}_{3} / \text { ground } \\
\text { steel }^{\mathrm{a}}\end{array}$ & Al/grit blasted steel ${ }^{\mathrm{b}}$ \\
\hline Thickness/ $\mu \mathrm{m}$ & $309 \pm 18^{c}$ & $320 \pm 14^{c}$ & $381 \pm 21^{c}$ \\
\hline \multicolumn{4}{|c|}{$\begin{array}{l}\text { a The steel surface was ground with } 240 \text { grit } \operatorname{SiC} \text { paper }\left(R_{a} \sim 0.5 \mu \mathrm{m}\right) \text {. } \\
\text { b The steel surface was grit blasted with alumina particles using a cold spray } \\
\text { ystem with coating deposition parameters }\left(R_{a} \sim 5 \mu \mathrm{m}\right) \text {. } \\
\text { c The standard deviations were determined for } 5 \text { sprayed samples, with } 10 \text { mea- } \\
\text { ures of thickness at different places of each sample. }\end{array}$} \\
\hline
\end{tabular}

ings as basically consisting of some pores in the top layer and dense bottom layer.

XRD patterns (Fig. 3S, Supplementary data) revealed that only one phase attributed to $\mathrm{Al}$ was found in $\mathrm{Al}$ coatings, and two phases attributed to $\mathrm{Al}$ and $\mathrm{Al}_{2} \mathrm{O}_{3}$ were found in the reinforced sample, both identical the phases found in starting materials. This means that no changes in the chemical composition of start material occurs using CGS technology. The reason is that CGS uses kinetic energy instead of thermal energy together with relatively low temperatures, which leads to oxide-free coatings and free of unwanted chemical reactions $[2,8,32]$.

In developing the $\mathrm{Al}$ and reinforced coatings, the results clearly indicated improvement in terms of adhesion and density of the coatings as pressure and temperature increased from low to high values until reaching the optimal values (data not shown). Some authors attribute the differences in the structure of splats forming the Al coating to factors such as kinetic energy of the particles during spraying, particle characteristics and variations in the substrate and its geometry [26]. By increasing pressure and temperature the thickness of the coatings also changes considerably. Depending on the chosen conditions, the coating was obtained with higher efficiency and good adhesion to the substrate, although it was porous. The adherence of the coatings obtained with optimized parameters was found to be in the range from 25 to $30 \mathrm{MPa}$ (ASTM F1147 (2005) Standard Practice). TAO et al. [25] have deposited reinforced coating on etched substrate with $\mathrm{Al}_{2} \mathrm{O}_{3}$ with adhesion reaching to $42 \mathrm{MPa}$. Other studies have also reported good adhesion of aluminum coatings deposited by CGS $[23,26,29]$.

The microhardness of $\mathrm{Al}$ coating was $51 \pm 3 \mathrm{HV}_{0.1}$, while for reinforced coating microhardness amounts to $65 \pm 5 \mathrm{HV}_{0.1}$ at the top layer, which represented a $22 \%$ increase. The coating was also produced using the optimized conditions, but with more layers to increase the thickness with good adhesion to the substrate and low porosity.

Table 1 shows the thickness of the coatings here studied and gives an idea about the efficiency of depositing under the optimal spraying conditions; it means that all spraying parameters were the same for all studied coatings.

The coating deposited on grit blasted steel is thicker than the one deposited on ground steel, probably due to the higher efficiency of Al deposition on grit blasted substrate. Similar effect was observed [36] by depositing Al on plates of alumina, where a greater amount of $\mathrm{Al}$ was deposited on grit blasted than on polished alumina surface. $\mathrm{Al}-\mathrm{Al}_{2} \mathrm{O}_{3}$ composite coatings with different $\mathrm{Al}_{2} \mathrm{O}_{3}$ particle shapes prepared on $\mathrm{Si}$ (hard) and $\mathrm{Al}$ (soft) substrate by cold spray showed that big craters were formed when great $\mathrm{Al}_{2} \mathrm{O}_{3}$ particles were sprayed on hard substrate, while the spraying of $\mathrm{Al}$ on hard substrate makes difficult to get good adhesion, suggesting that the composite coating would have some advantages [37]. It is also observed that no appreciable difference was found when both substrates had similar surface preparation. In the case of $\mathrm{Al} / \mathrm{Al}-\mathrm{Al}_{2} \mathrm{O}_{3}$ coating, the reinforced top layer is around $130 \mu \mathrm{m}$ thick. 

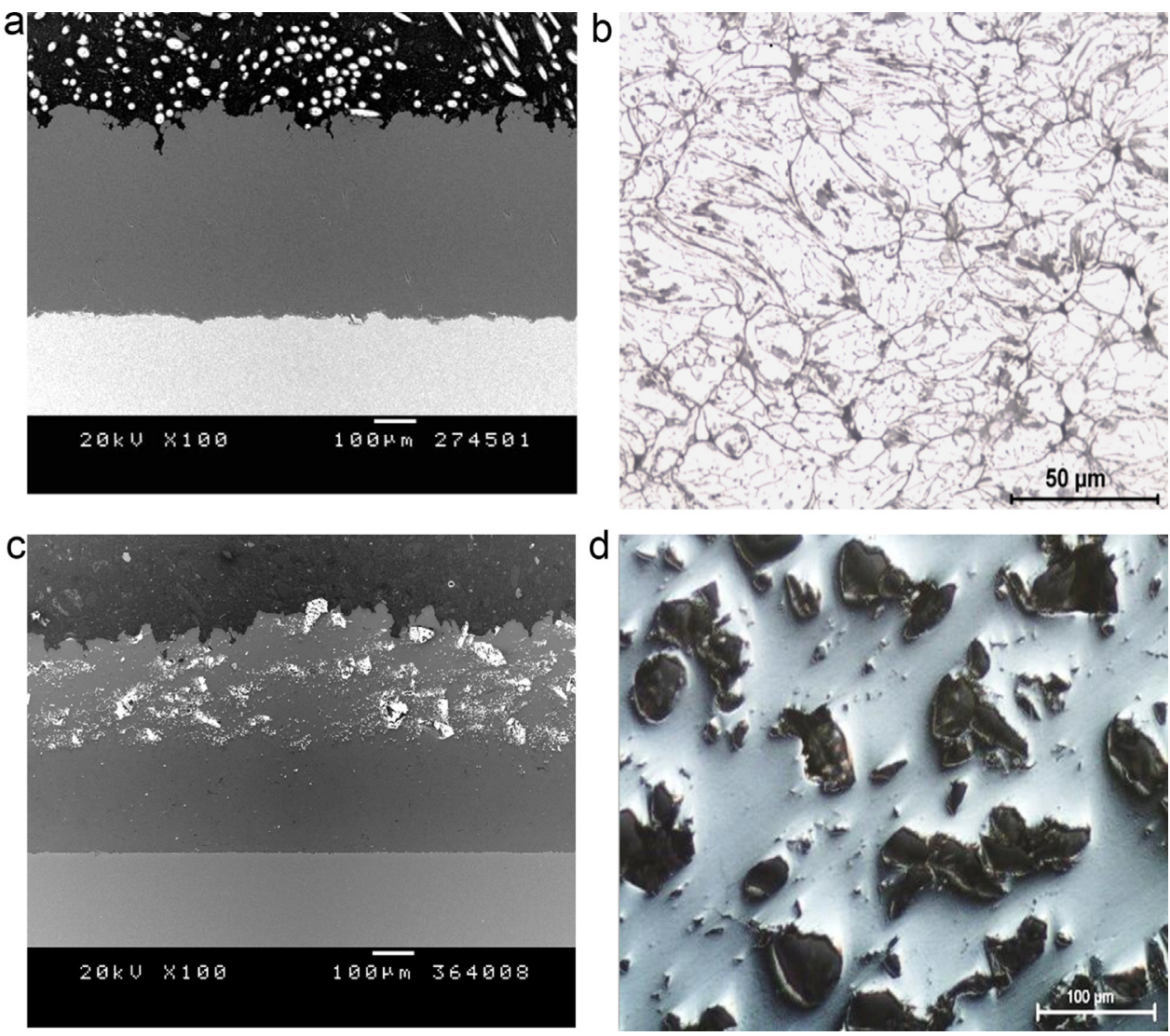

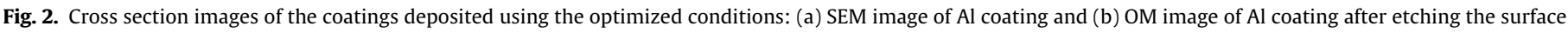
with the Keller's reagent for $15 \mathrm{~s}$. (c) SEM image of $\mathrm{Al}_{-}-\mathrm{Al}_{2} \mathrm{O}_{3} / \mathrm{Al}$ coating. (d) OM image of $\mathrm{Al}_{-}-\mathrm{Al}_{2} \mathrm{O}_{3} / \mathrm{Al}$ coating without attack.

Table 2

Main wear properties of $\mathrm{Al}$ and $\mathrm{Al}-\mathrm{Al}_{2} \mathrm{O}_{3} / \mathrm{Al}$ coatings.

\begin{tabular}{|c|c|c|}
\hline & $\mathrm{Al} /$ ground steel & $\begin{array}{l}\mathrm{Al}-\mathrm{Al}_{2} \mathrm{O}_{3} / \mathrm{Al} / \text { ground } \\
\text { steel }\end{array}$ \\
\hline Friction coefficient & $0.41 \pm 0.02$ & $0.57 \pm 0.01$ \\
\hline Volume loss $/\left(\mathrm{mm}^{3} / \mathrm{Nm}\right)$ & $(9 \pm 2) \times 10^{-4}$ & $(6 \pm 1) \times 10^{-4}$ \\
\hline Wear track depth/ $\mu \mathrm{m}$ & $(283 \pm 18)$ & $(90 \pm 10)$ \\
\hline
\end{tabular}

a The deviation was obtained determining the average of two measures and calculating the standard deviation.

\subsection{Mechanical properties}

\subsubsection{Sliding wear resistance}

The addition of $\mathrm{Al}_{2} \mathrm{O}_{3}$ particles as reinforcement on aluminum coatings obtained by CGS decreases significantly the wear. After a sliding distance of $1000 \mathrm{~m}$ onto the $\mathrm{Al}-\mathrm{Al}_{2} \mathrm{O}_{3} / \mathrm{Al}$ coating, the wear track depth was $90.1 \mu \mathrm{m}$ (Table 2). Fig. 3 shows the SEM of the wear tracks and profiles of $\mathrm{Al}$ and $\mathrm{Al}-\mathrm{Al}_{2} \mathrm{O}_{3} / \mathrm{Al}$ coatings, respectively. In the case of pure aluminum coating, the wear track depth was $283 \pm 18 \mu \mathrm{m}$, around three times the value obtained for $\mathrm{Al}-\mathrm{Al}_{2} \mathrm{O}_{3} / \mathrm{Al}$ coating.

Typical wear tracks from a pure $\mathrm{Al}$ and $\mathrm{Al}-\mathrm{Al}_{2} \mathrm{O}_{3} / \mathrm{Al}$ cold spray coatings are shown in Fig. 3. For pure Al coating (Fig. 3(a)) the smeared appearance of the surface is typical of adhesive wear, and the wear track profiles show evidence of ploughing and extrusion of the worn material outside the wear track. The loose wear debris had the same color and appearance of the coating material, again suggesting an adhesive wear mode. It was also observed $\mathrm{Al}$ adhered on the steel counter ball surface which indicates adhesive wear mechanism. On the other hand, the ball appears to be virtually unworn. This is a case of adhesive material transfer from the softer coating to the harder counter material. Fig. 3b shows a wear track from an $\mathrm{Al}-10 \% \mathrm{Al}_{2} \mathrm{O}_{3} / \mathrm{Al} /$ steel coating, which shows signs of smearing and adhesive wear as in the pure $\mathrm{Al}$ coatings, but there is also some evidence of abrasive wear. The wear debris was a mixture of light colored material like that of the coating, but also dark debris suggesting some oxidation of the wear debris.

These results indicate that $\mathrm{Al}_{2} \mathrm{O}_{3}$ particles may act as lubricants diminishing the wear. Therefore, the principal mechanism of wear that is active in the $\mathrm{Al}$ coating samples is adhesive wear, like pure $\mathrm{Al}$. For the reinforced aluminum coating, $\mathrm{Al}-\mathrm{Al}_{2} \mathrm{O}_{3} / \mathrm{Al}$, abrasive wear due to wear particles dislodged from sliding surfaces.

\subsubsection{Rubber wheel}

Abrasion tests were performed after applying the same treatment to that of slider wear resistance measurements. All samples were tested with the initial $R_{a}$, which was $\sim 5 \mu \mathrm{m}$ for $\mathrm{Al} /$ grit blasted steel and around $0.5 \mu \mathrm{m}$ for the others. Abrasion tests showed that the abrasive wear rate slowly decreased for short times (2-3 min) and remained constant until the end of test at $1.9 \times 10^{-4} \mathrm{~mm}^{3} / \mathrm{Nm}$, while the $\mathrm{Al}-\mathrm{Al}_{2} \mathrm{O}_{3} / \mathrm{Al}$ coating had the abrasive wear rate slightly increased during the first $3 \mathrm{~min}$ and stabilized at $1.7 \times 10^{-4} \mathrm{~mm}^{3} / \mathrm{Nm}$. The variation of abrasive wear between the two samples rate, at very short times, may be due to the differences in the state of the initial surface: the surface roughness of $\mathrm{Al}$ coating decreases as the elapsed time increases and reaches the

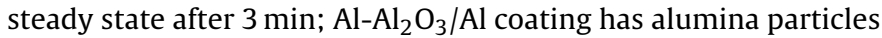
at the surface, and shows some porosity. Therefore, at the beginning, the hard particles become the surface harder with a lower abrasive wear rate than $\mathrm{Al}$ coating and as the time goes by and the more porous layer is removed, the abrasive rate increases to 

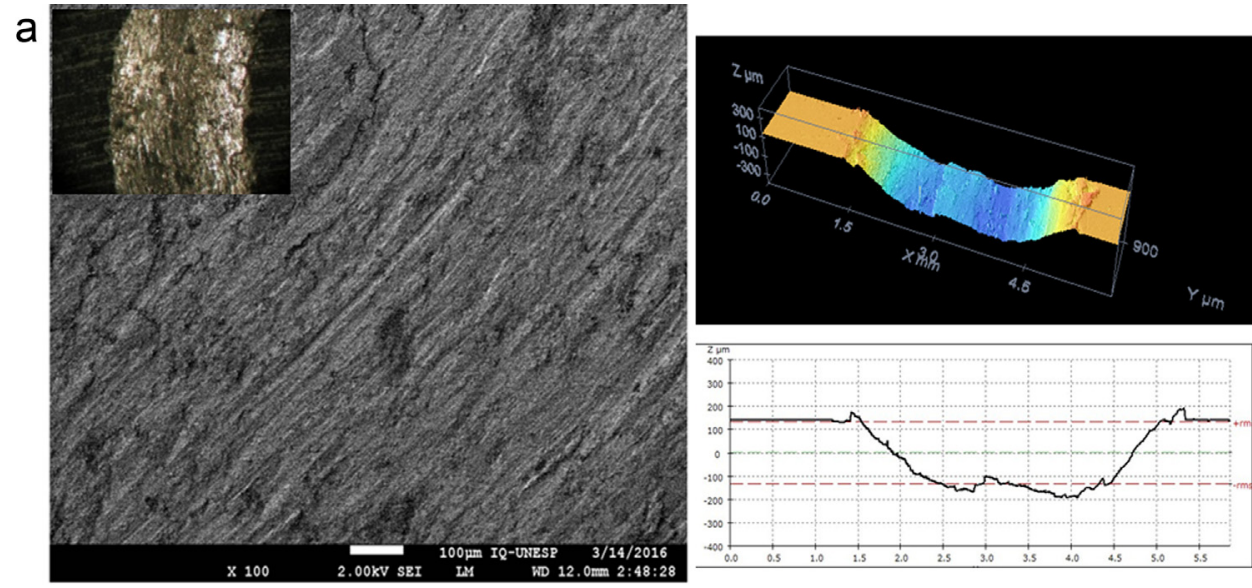

b
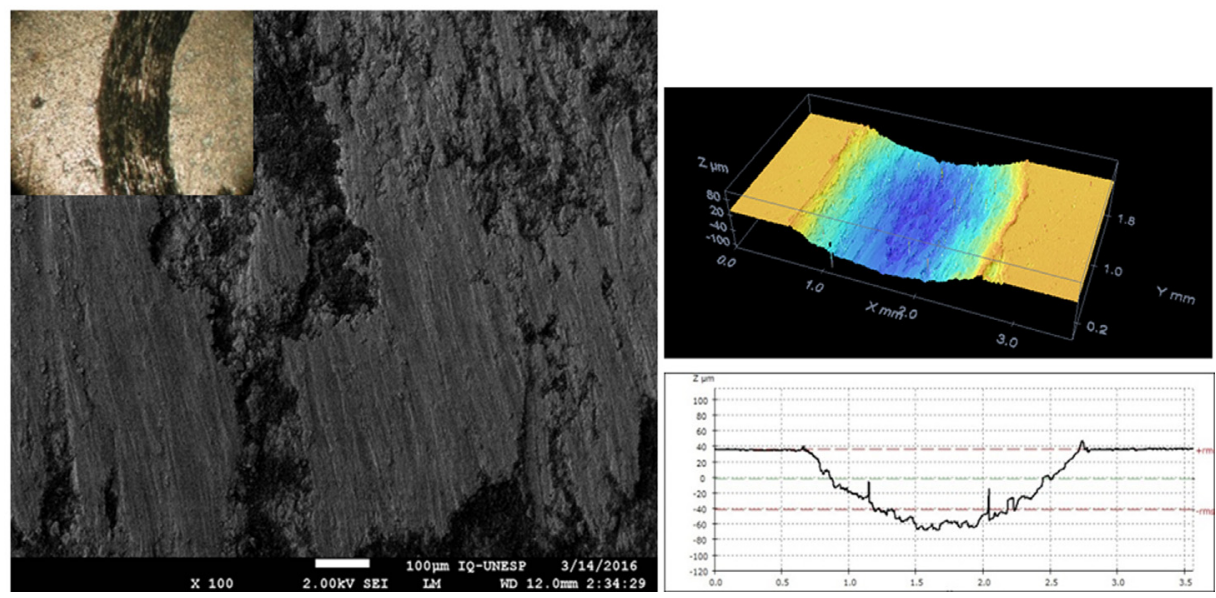

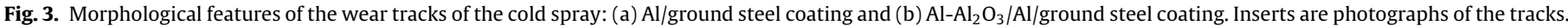

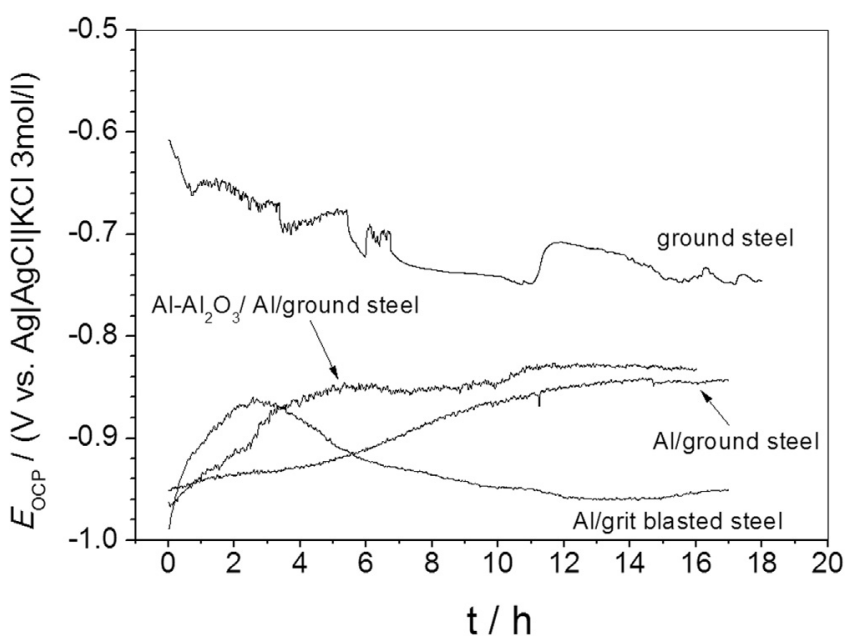

Fig. 4. Open circuit potential vs. time for all studied samples measured in aerated and unstirred $3.5 \mathrm{wt} \% \mathrm{NaCl}$ solution for relatively short immersion times, at $25^{\circ} \mathrm{C}$.

reach the steady state, but with an abrasive wear rate lower than Al coating.

\subsection{Corrosion studies}

\subsubsection{Open circuit potential and cyclic polarization studies}

First it will be discussed electrochemical results obtained at short immersion times. Fig. 4 shows the open circuit potential
( $\left.E_{\mathrm{OCP}}\right)$ versus time in aerated and unstirred 3.5\% $\mathrm{NaCl}$ solution for substrate and coatings during the first $18 \mathrm{~h}$ of immersion.

$E_{\mathrm{OCP}}$ values of steel decreased almost continuously from $0.60 \mathrm{~V}$ to $-0.74 \mathrm{~V} / \mathrm{Ag}|\mathrm{AgCl}| \mathrm{KCl} 3 \mathrm{~mol} / \mathrm{l}$ with small variations during the time course of the experiment. It is well-known that common steel does not passive in chloride solution, mainly in neutral with high chloride concentration, acid or extremely alkaline solutions, and that native iron oxide grows on the steel surface by thermodynamical reasons. The conditions for passivation of iron or low carbon steel are strict, for instance, pure iron can become passive, even in neutral chloride-containing solution depending on the chloride concentration and the anodic potential applied [38]. At chloride concentrations normally used for corrosion tests to simulating sea water (3.4 or $3.5 \mathrm{wt} \%$ ) the $E_{\mathrm{OCP}}$ values decrease and stabilize around $-0.7 \mathrm{~V} / \mathrm{Ag}|\mathrm{AgCl}| \mathrm{KCl} 3 \mathrm{~mol} / \mathrm{l}[39,40]$ and no passive state can be observed. Therefore, the $E_{\mathrm{OCP}}$ measured for common steel clearly indicates an active state due to the presence of oxygen, water and chloride, conditions in which the common steel is active at open circuit. The initial potential decrease can be associated to many factors such as chloride adsorption, dissolution of iron oxides by chloride ions, changes in the oxygen and metallic ions concentration, and agrees with the values obtained before $[39,40]$. At open circuit potential, the cathodic and anodic simultaneous electrochemical reactions are occurring spontaneously; the main reactions involved in the electrode process are the adsorption of chloride on iron oxide surface, chloride penetration and oxides dissolution assisted by the chloride ions [41], oxygen reduction (cathodic reaction) and iron oxidation (anodic reaction) to soluble species. 


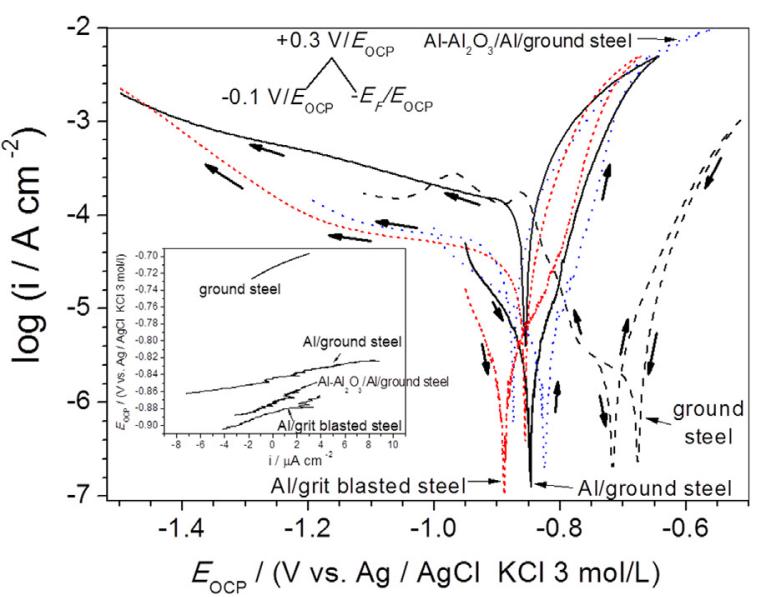

Fig. 5. Cyclic polarization of steel substrate and coated samples recorded in nondeaerated and quiescent $3.5 \mathrm{wt} \% \mathrm{NaCl}$ solution at $0.166 \mathrm{mV} / \mathrm{s}$ and after $\sim 18 \mathrm{~h}$ of immersion. Within the frame: potential program applied in $\mathrm{V} / E_{\mathrm{OCP}}$ where the initial was $-0.1 \mathrm{~V}$, reverse $+0.3 \mathrm{~V}$ and the final potential was $E_{\mathrm{F}}$ at $0.166 \mathrm{mV} / \mathrm{s}$.

For all Al-based as-sprayed coatings the behavior of $E_{\mathrm{OCP}}$ is completely different from the low carbon steel. $E_{\mathrm{OCP}}$ values increased during the first hours of immersion indicating the formation of aluminum oxide and tended to stabilize for $\mathrm{Al}(-0.84 \mathrm{~V} / \mathrm{Ag}|\mathrm{AgCl}| \mathrm{KCl} 3 \mathrm{~mol} / \mathrm{l})$ and $\mathrm{Al}_{-} \mathrm{Al}_{2} \mathrm{O}_{3} / \mathrm{Al}$ $(-0.83 \mathrm{~V} / \mathrm{Ag}|\mathrm{AgCl}| \mathrm{KCl} 3 \mathrm{~mol} / \mathrm{l})$ coatings deposited on ground steel, while after almost $3 \mathrm{~h}$, the $E_{\mathrm{OCP}}$ decreases for $\mathrm{Al} /$ grit blasted steel sample and stabilizes at still more negative values at $-0.95 \mathrm{~V} / \mathrm{Ag}|\mathrm{AgCl}| \mathrm{KCl} 3 \mathrm{~mol} / \mathrm{l}$. The increase of the $E_{\mathrm{OCP}}$ values for aluminum and its alloys in neutral and $\mathrm{O}_{2}$-saturated solution containing $0.1 \mathrm{~mol} / 1 \mathrm{NaCl}$ was also previously observed [42]. The reason for the different behavior of the $E_{\mathrm{OCP}}$ for the Al coating applied on grit blasted steel and ground steel is not clear yet.

As-sprayed samples were used to estimate the corrosion parameters (Table 3 ) from the small amplitude linear polarization and cyclic polarization curves as described in Supplementary data. From the SALP data (insert of Fig. 5), the as-sprayed reinforced coating showed a slightly higher corrosion resistance compared to the pure Al coatings, which showed similar polarization resistance as observed for series ASTM $1200 \mathrm{Al}$ alloy [43]. The reason for that can be the decrease of the active area in the composite coating due to the replacing of some $\mathrm{Al}$ particles by $\mathrm{Al}_{2} \mathrm{O}_{3}$ particles on the electrode surface.

Fig. 5 shows the cyclic polarization curves for all coatings and substrate by applying the potential program (insert), where $E_{\mathrm{F}}$ values (the final potential) are $-1.1 \mathrm{~V} / \mathrm{Ag}|\mathrm{AgCl}| \mathrm{KCl} 3 \mathrm{~mol} / \mathrm{l}$ for steel, $-1.2 \mathrm{~V} / \mathrm{Ag}|\mathrm{AgCl}| \mathrm{KCl} 3 \mathrm{~mol} / \mathrm{l}$ for $\mathrm{Al}-\mathrm{Al}_{2} \mathrm{O}_{3} / \mathrm{Al} /$ ground steel, and $-1.5 \mathrm{~V} / \mathrm{Ag}|\mathrm{AgCl}| \mathrm{KCl} 3 \mathrm{~mol} / \mathrm{l}$ for $\mathrm{Al}$ on ground and grit blasted steel. The $i_{\text {corr }} \cong 10^{-5} \mathrm{~A} \mathrm{~cm}^{-2}$ and, for $E>E_{\text {corr }}$ the anodic current increased up to reversing the potential scan. For all coatings, the current density on the reversing scan was higher than in the direct one, which indicates an increase in the active area due to the aluminum dissolution and the formation of defects and pits during the direct scan (see Fig. 5S, Supplementary data). The corrosion potential was around $(-0.85 \pm 0.03) \mathrm{V} / \mathrm{Ag}|\mathrm{AgCl}| \mathrm{KCl} 3 \mathrm{~mol} / 1$, which is near the $E_{\mathrm{OCP}}$ values that were measured after around $18 \mathrm{~h}$ of immersion and obtained by SALP technique (Table 3), indicating an active system at open circuit and in the experimental conditions. The $b_{\mathrm{a}}$ values were around $0.05 \mathrm{~V} /$ decade and $b_{\mathrm{c}}$ values were not obtained (except for reinforced sample) since the cathodic process is a process limited by diffusion, and $R_{\mathrm{p}}$ values have followed the order: $\mathrm{Al}-\mathrm{Al}_{2} \mathrm{O}_{3} / \mathrm{Al} /$ ground steel $>\mathrm{Al} /$ ground steel $\approx \mathrm{Al} /$ grit blasted steel $>$ steel substrate. These values are lower than those obtained from SALP method but in the same order of magnitude.
For steel, the current also increases during the direct scan, but slightly decreased in the reverse scan, suggesting that products of steel corrosion were formed and deposited on the surface. The corrosion potential was $\sim 0.1 \mathrm{~V}$ more negative than the value observed in the reverse scan with slow increased of the current between -0.70 and $-0.76 \mathrm{~V} / \mathrm{Ag}|\mathrm{AgCl}| \mathrm{KCl} 3 \mathrm{~mol} / \mathrm{l}$, suggesting some impediment of current flow due to the products of corrosion deposited on the electrode. As the potential was made more negative, the current increased 2 orders of magnitude in two stages until $-0.86 \mathrm{~V} / \mathrm{Ag}|\mathrm{AgCl}| \mathrm{KCl} 3 \mathrm{~mol} / \mathrm{l}$ followed by at least two steps more with a small increase in the current density. This is clearly evidenced by comparing the cyclic polarization (Fig. 5) and cathodic polarization (Fig. 4S) curves of steel. On the other hand, for the Albased coatings, the cathodic polarization curves in Figs. 5 and $4 \mathrm{~S}$ are similar, thus demonstrating that the substrate was not involved.

The mechanisms of iron dissolution in acid solutions containing halides are based on those proposed for acid medium. Bockris, Drazic, Despic (BDD) mechanism [44] have proposed the basic mechanism of iron dissolution in acid medium, in which the inconsistencies pointed out on the catalytic mechanism proposed by Heusler were removed [in Ref. [45]. This mechanism was modified by Kelly [46] to give the Bockris-Kelly mechanism:

$\mathrm{Fe}+\mathrm{H}_{2} \mathrm{O} \rightleftarrows \mathrm{Fe} . \mathrm{H}_{2} \mathrm{O}_{\mathrm{ad}}$

Fe. $\mathrm{H}_{2} \mathrm{O}_{\mathrm{ad}} \rightleftarrows \mathrm{Fe}\left(\mathrm{OH}^{-}\right)_{\mathrm{ad}}+\mathrm{H}^{+}$

$\mathrm{Fe}\left(\mathrm{OH}^{-}\right)_{\mathrm{ad}} \rightleftarrows(\mathrm{FeOH})_{\mathrm{ad}}+\mathrm{e}^{-}$

$(\mathrm{FeOH})_{\mathrm{ad}} \rightleftarrows(\mathrm{FeOH})^{+}+\mathrm{e}^{-}$rate - det er min ing

$(\mathrm{FeOH})^{+}+\mathrm{H}^{+} \rightleftarrows \mathrm{Fe}^{2+}+\mathrm{H}_{2} \mathrm{O}$

Depending on the applied potential and the surface $\mathrm{pH}$, the $(\mathrm{FeOH})_{\text {ad }}$ species may partially cover the bare surface or to be dissolved via Eqs. (4) and (5) or grow to form a passive oxide film. The effect of chloride ions on iron dissolution has been studied mainly in acidic medium and it is well-known that halides may cause certain inhibition of iron dissolution due to their strong adsorption on the metal surface. The effect of chloride in acid medium $(\mathrm{pH} \leq 5)$ was extensively investigated [47-50]. For an acid solution with chloride, the following mechanism has been proposed for iron dissolution [48]:

$\mathrm{Fe}+\mathrm{H}_{2} \mathrm{O} \rightleftarrows \mathrm{Fe} . \mathrm{H}_{2} \mathrm{O}_{\mathrm{ad}}$

Fe. $\mathrm{H}_{2} \mathrm{O}_{\mathrm{ad}}+\mathrm{X}^{-} \rightleftarrows \mathrm{FeX}^{-}{ }_{\mathrm{ad}}+\mathrm{H}_{2} \mathrm{O}$

Fe. $\mathrm{H}_{2} \mathrm{O}_{\mathrm{ad}}+\mathrm{X}^{-} \rightleftarrows \mathrm{FeOH}_{a d}^{-}+\mathrm{H}^{+}+\mathrm{X}^{-}$

$\mathrm{FeX}_{\mathrm{ad}}^{-}+\mathrm{FeOH}_{\mathrm{ad}}^{-} \rightleftarrows \mathrm{FeOH}^{+}+\mathrm{Fe}+\mathrm{X}^{-}+2 \mathrm{e}^{-}$(rate-determining)

followed by Eq. (5). For lower chloride concentration $(\leq 1.9 \mathrm{~mol} / \mathrm{l})$ and acid solution, Chin and Nobe [49] have proposed the formation of $(\mathrm{FeClOH})^{-}$adsorbed species, which is oxidized and then dissolved in acid to form ferrous and chloride ions. The $(\mathrm{FeCl})_{\text {ad }}$ intermediate was proposed at high chloride concentration and very acid solutions [50]. However, the effect of chloride ions depends on the current density for a given $\mathrm{pH}$ and chloride concentration because the chloride adsorption can be slower than the iron dissolution, and then no significant effect of chloride is observed.

In neutral chloride-containing aqueous solution and at low anodic potentials, the Eqs. (1)-4) are accepted to be involved in the iron dissolution [51,52] and depending on the chloride concentration $(\leq 0.01 \mathrm{~mol} / \mathrm{l})$ the repassivation of iron is possible, but in high chloride concentration, the effect of chloride on the dissolution of the passive film is dominant and accelerates the iron dissolution. Burstein and Davis [52] have considered that $(\mathrm{FeCl})_{\mathrm{ad}}$ species are formed parallel with $\mathrm{Fe}\left(\mathrm{OH}^{-}{ }_{\mathrm{ad}}\right.$ and $\mathrm{FeOH}_{\mathrm{ad}}$ species, and 
Table 3

Corrosion parameters estimated from the small amplitude linear polarization and cyclic polarization ${ }^{\mathrm{a}}$ curves. $^{-}$

\begin{tabular}{|c|c|c|c|c|}
\hline $\begin{array}{l}\text { Sample } \\
\text { Parameter }\end{array}$ & Ground steel substrate & $\mathrm{Al} /$ ground steel & $\mathrm{Al}-\mathrm{Al}_{2} \mathrm{O}_{3} / \mathrm{Al} /$ ground steel & $\mathrm{Al} /$ grit blasted steel \\
\hline${ }^{\mathrm{b}} R_{\mathrm{p}} / \mathrm{k} \Omega \mathrm{cm}^{2}$ & $3.8 \pm 0.2$ & $3.3 \pm 0.3$ & $6.7 \pm 0.9$ & $5.2 \pm 0.9$ \\
\hline${ }^{\mathrm{b}} E_{\mathrm{i} \rightarrow 0} / \mathrm{mV} / \mathrm{Ag}|\mathrm{AgCl}| \mathrm{KCl} 3 \mathrm{~mol} / \mathrm{l}$ & $-712 \pm 1$ & $-845 \pm 1$ & $-873 \pm 1$ & $-887 \pm 2$ \\
\hline$E_{\text {corr }} /\left.\mathrm{mV}\right|_{\mathrm{Ag}|\mathrm{AgCl}| \mathrm{KCl} 3 \mathrm{~mol} / \mathrm{l}}$ & $-716 \pm 1$ & $-847 \pm 2$ & $-826 \pm 1$ & $-889 \pm 1$ \\
\hline$i_{\text {corr }} / \mu \mathrm{Acm}^{-2}$ & 23.5 & 13.5 & 9.5 & 10.6 \\
\hline$b_{\mathrm{a}} / \mathrm{mV} \mathrm{dec}^{-1}$ & $63 \pm 2$ & $58 \pm 1$ & $45 \pm 2$ & $53 \pm 3$ \\
\hline$b_{\mathrm{c}} / \mathrm{mV} \mathrm{dec}^{-1}$ & - & - & $-(109 \pm 2)$ & - \\
\hline${ }^{\mathrm{a}} R_{\mathrm{p}} / \mathrm{k} \Omega \mathrm{cm}^{2}$ & 1.2 & 1.9 & 2.4 & 1.8 \\
\hline
\end{tabular}

a The values were obtained by measuring the cathodic polarization and the cyclic polarization, and the $R_{\mathrm{p}}$ values and $i_{\text {corr }}$ obtained as explained in Supplementary data.

b From small amplitude linear polarization, $R$ p value was the average of two samples with 3 curves each sample.

therefore, a mechanism like that proposed by Kuo and Nobe [50] can be considered.

The main reduction reaction in neutral and oxygenated $\mathrm{NaCl}$ solution is the oxygen reduction to hydroxide groups [31,53]:

$\mathrm{O}_{2}+2 \mathrm{H}_{2} \mathrm{O}+4 \mathrm{e}^{-} \rightleftarrows 4 \mathrm{OH}^{-}$

Bare $\mathrm{Al}$ is rapidly ionized to form $\mathrm{Al}^{3+}$ ion. In neutral chloride solution, anodic and cathodic processes of aluminum corrosion are respectively dissolution of aluminum and reduction of dissolved oxygen, in according the following reactions:

$\mathrm{Al} \rightarrow \mathrm{Al}^{3+}+3 \mathrm{e}^{-}$

and from these two reactions aluminum ions react with hydroxide to give aluminum hydroxide, resulting the global reaction (Eq. (10)):

$4 \mathrm{Al}+3 \mathrm{O}_{2}+6 \mathrm{H}_{2} \mathrm{O} \rightarrow 4 \mathrm{Al}(\mathrm{OH})_{3}$

To investigate the water reduction as a possible cathodic reaction, cathodic polarization curves were recorded for steel and coated steel. Fig. 4S (Supplementary data) shows the cathodic polarizations recorded from $+0.020 \mathrm{~V} / E_{\mathrm{OCP}}$ to $-1.1 \mathrm{~V} / E_{\mathrm{OCP}}$. For steel the reduction of water seems begin at potentials around $-1.1 \mathrm{~V} / \mathrm{Ag}|\mathrm{AgCl}| \mathrm{KCl} 3 \mathrm{~mol} / \mathrm{l}$ while for the Al-based coatings it begins at $-1.3 \mathrm{~V} / \mathrm{Ag}|\mathrm{AgCl}| \mathrm{KCl} 3 \mathrm{~mol} / \mathrm{l}$. It is clear seen a cathodic current plateau at potentials more negative than $E_{\mathrm{OCP}}$, indicating a diffusion controlled process, which should be related to the reduction of oxygen. During the reduction of the water, at more negative potentials, gas evolution was observed which can be associated to the following reaction:

$2 \mathrm{H}_{2} \mathrm{O} \rightarrow \mathrm{H}_{2}+2 \mathrm{OH}^{-}+2 \mathrm{e}^{-}$

So, the main cathodic reaction on steel and Al-based coatings is the oxygen reduction which agrees with previous works [28,54,55].

The aluminum hydroxide precipitated on the surface can slowly be converted in aluminum oxide $\left(\mathrm{Al}_{2} \mathrm{O}_{3}\right)$, but this oxide does not offer enough protection to the aluminum in the presence of aggressive ions such as chloride, then, it can be dissolved via a queuing mechanism [41]. The small size of $\mathrm{Cl}^{-}$ions allows its penetration through the passive film provoking the aluminum oxide dissolution and when reaches the bare Al localized corrosion occurs in according the following reactions [56]:

$\mathrm{Al}^{3+}+\mathrm{H}_{2} \mathrm{O} \rightleftarrows \mathrm{Al}(\mathrm{OH})^{2+}+\mathrm{H}^{+}$

$\mathrm{Al}(\mathrm{OH})^{2+}+\mathrm{Cl}^{-} \rightleftarrows \mathrm{Al}(\mathrm{OH}) \mathrm{Cl}^{+}$

$\mathrm{Al}(\mathrm{OH}) \mathrm{Cl}^{+}+\mathrm{H}_{2} \mathrm{O} \rightleftarrows \mathrm{Al}(\mathrm{OH})_{2} \mathrm{Cl}+\mathrm{H}^{+}$

Solution extracted from the interior of the artificial pits showed the presence of two salts: $\mathrm{Al}(\mathrm{OH})_{2} \mathrm{Cl}$ and $\mathrm{Al}(\mathrm{OH}) \mathrm{Cl}_{2}$ [57] that stabilize and maintain a low $\mathrm{pH}$ inside the pit.

Cross section SEM images after cyclic polarization (Fig. 5S(a) and (b) Supplementary data) indicated that a brittle zone is formed inside the coatings, $50-80 \mu \mathrm{m}$ from the top layer, in which cracks

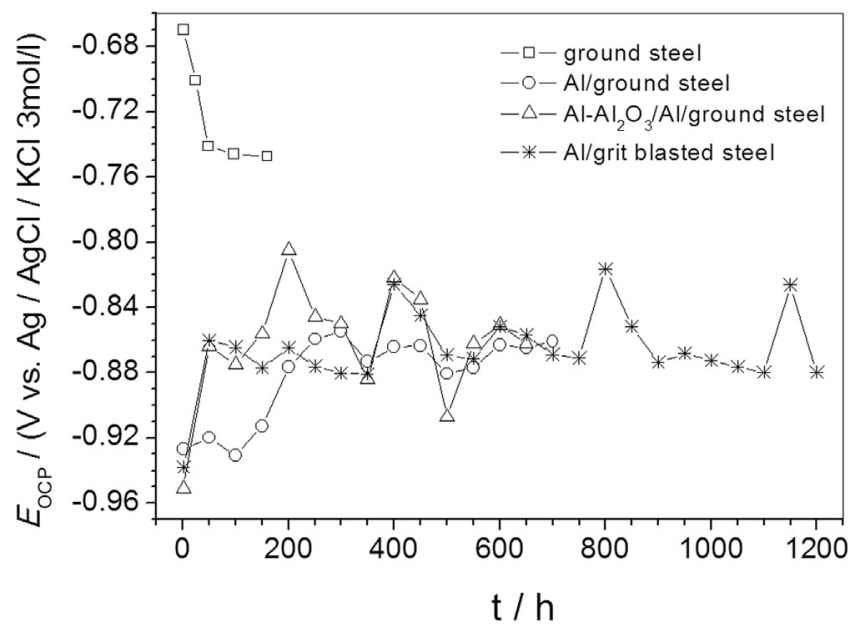

Fig. 6. $E_{\mathrm{OCP}}$ versus time measured in aerated and unstirred $3.5 \mathrm{wt} \% \mathrm{NaCl}$ solution for the steel and different coated samples for relatively high immersion times.

are easily developed during the cross section preparation. The applied potential also favored the increase of stress in this region due to accelerate the growth of aluminum oxide and electrolyte penetration, but the inner layer of the coating and the substrate seem not to be affected by the polarization.

The substrate and coatings were also examined by $E_{\mathrm{OCP}}$ measurements for different immersion times depending on the material: steel substrate $(96 \mathrm{~h}), \mathrm{Al}$ on ground steel $(\sim 700 \mathrm{~h})$ and on grit blasted steel $(\sim 1210 \mathrm{~h})$, and $\mathrm{Al}-\mathrm{Al}_{2} \mathrm{O}_{3} / \mathrm{Al} /$ ground steel $(\sim 650 \mathrm{~h})$. The $\mathrm{Al} / \mathrm{grit}$ blasted steel was observed until $2200 \mathrm{~h}$ of immersion to identify a possible attack of the electrolyte on the aluminum/substrate interface (Fig. 6). For steel the $E_{\mathrm{OCP}}$ value decreased from $-0.67 \mathrm{~V} / \mathrm{Ag}|\mathrm{AgCl}| \mathrm{KCl} 3 \mathrm{~mol} / \mathrm{l}$ to around $-0.75 \mathrm{~V} / \mathrm{Ag}|\mathrm{AgCl}| \mathrm{KCl} 3 \mathrm{~mol} / \mathrm{l}$ after $45 \mathrm{~h}$ of immersion and maintained stable until the end of test $(160 \mathrm{~h})$. The decrease of $E_{\mathrm{OCP}}$ with time can be associated, respectively, to the dissolution of natural oxide present on steel, the adsorption of $\mathrm{Cl}^{-}$ion on the electrode surface, and the consequent consumption of oxygen and diffusion of the iron species to the solution.

For $\mathrm{Al}$ and $\mathrm{Al}-\mathrm{Al}_{2} \mathrm{O}_{3} / \mathrm{Al}$ coatings (Fig. 6) the $E_{\mathrm{OCP}}$ values oscillated and increased in the first hours of immersion and up to $200 \mathrm{~h}$ for the $\mathrm{Al} /$ grit blasted steel sample. After these periods, the $E_{\mathrm{OCP}}$ values have oscillated with time around $-0.87 \mathrm{~V} / \mathrm{Ag}|\mathrm{AgCl}| \mathrm{KCl} 3 \mathrm{~mol} / \mathrm{l}$ with different amplitudes not higher than $0.1 \mathrm{~V}$ for all coatings; this value of $E_{\mathrm{OCP}}$ suggests that the substrate was not attacked by the electrolyte yet, since the potential of the substrate is around $-0.75 \mathrm{~V} / \mathrm{Ag}|\mathrm{AgCl}| \mathrm{KCl} 3 \mathrm{~mol} / \mathrm{l}$.

For the coatings, the oscillations of potential are caused by the formation/repassivation of pits on aluminum surface, probably by a queuing process [41], where chloride ions adsorb onto the oxide film, penetrate the film, then assist the localized dissolution at specific sites at the oxide/Al interface, leading to the formation of 


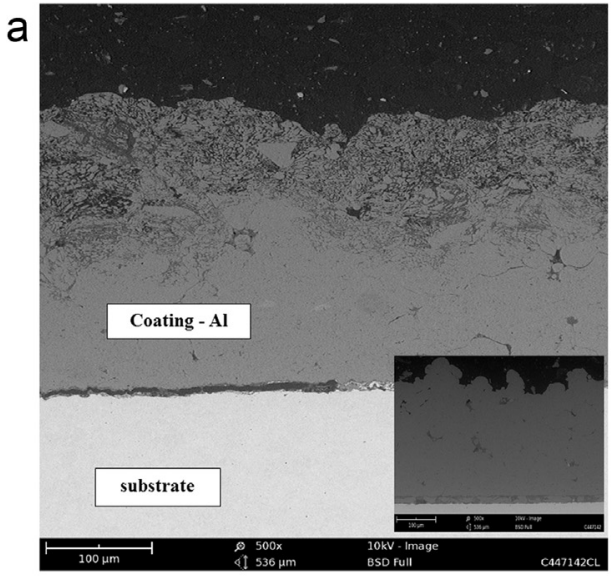

b

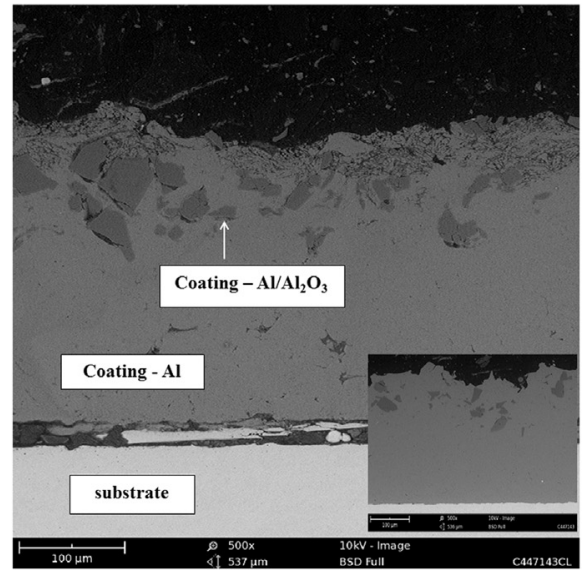

C

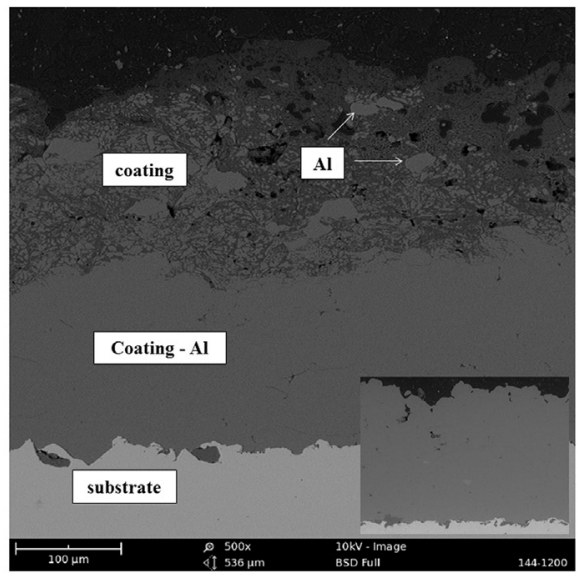

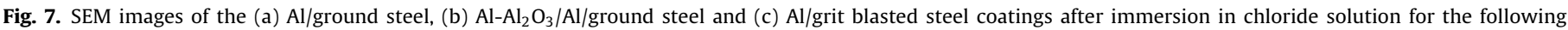
immersion times/h: (a) 710; (b) 650 and (c) 816 h. Inserts: Cross section SEM images of coatings before immersion in chloride solution.

oxide blisters that develop into pits. The pits begin to be formed on the thinner and/or defected aluminum oxide film in $\mathrm{Al}$ coatings (Fig. 7(a) and (c)) and mainly surrounding the $\mathrm{Al}_{2} \mathrm{O}_{3}$ particles in the reinforced $\mathrm{Al}$ coating (Fig. 7(b)). Corrosion around these particles can be explained, as usual, by the formation of local cells between them (more noble) and the Al matrix (more active).

At the beginning of immersion, the pores are enlarged due to the reaction with chloride ions, and then almost all the surface is damaged. It is clearly seen that the outer part of the coating, which is porous, is completely full of defects and/or pits and some particles of aluminum were not attacked, suggesting that the pitting process begins at the border of the greater Al particles by the dissolution of small ones (see the powder size distribution, Fig. 1Sa) and is spread all over the sample surface with time. The $\mathrm{Al}_{2} \mathrm{O}_{3}$ particles are practically inert in the neutral chloride-containing solution and the defects around the particles and on the matrix are the main sites for pitting initiation. At open circuit the surface of $\mathrm{Al} /$ ground steel coating seems to be more damaged than the reinforced coating, which suggests that the addition of alumina decreases the region attacked by the electrolyte, but the attack can be higher and dipper around the alumina particles (Fig. 6S). The $R_{\mathrm{p}}$ values (Table 3) and the corrosion potential (Fig. 5) for as-sprayed coatings also indicated a slightly higher corrosion resistance for reinforced coating, probably due to the higher content in alumina, which could decrease the active area, as mentioned above. The EDS analysis only showed aluminum and oxygen as the main elements in the outer layer and attacked region, and neither chloride nor oxygen were detected in coating/steel interface for all coatings and delamination was not observed on the coating/substrate interface, suggesting that the electrolyte did not reach the substrate up to $800 \mathrm{~h}$ of immersion. For $\mathrm{Al}-\mathrm{Al}_{2} \mathrm{O}_{3} / \mathrm{Al} /$ steel coating higher oxygen concentration was detected at the wetted region (outer layer) than in the rest of the reinforced coating, i.e., in the inner layer and on coating/substrate interface.

Considering that until around $816 \mathrm{~h}$ the substrate of the $\mathrm{Al} / \mathrm{grit}$ blasted sample seems not to be attacked by the electrolyte (Fig. 7(c)), another experiment was performed until around $2200 \mathrm{~h}$ of immersion. The $E_{\mathrm{OCP}}$ followed the same tendency that at lower immersion times, but the cross section SEM images (Fig. 8) revealed a strong attack and pathways followed by the electrolyte to arrive to the substrate (see the arrows, Fig. 8(a)).

The coating is damaged in a great extension with pathways, which allow the electrolyte to reach the substrate in some specific points, but not all over the coating/substrate interface. As a result of the local corrosion some cracks are developed inside the coating, which cannot be attributed to the cross section preparation (B in Fig. 8(b)). It is also interesting to note the presence of some almost intact island of Al distributed inside the coating (A in Fig. 8(b)). EDS analysis at the spots 1-3 in insert of Fig. 8(b) showed that: (a) aluminum, and some amount of Fe were detected in spots 1 (8.3 wt\%) and 2 (4.8 wt\%); (b) aluminum and oxygen are the main components in the wetted zone represented by spot 3, where $3.4 \mathrm{wt} \% \mathrm{Fe}$ was detected; (c) the amount of iron decreased from spots 1-3 and oxygen was undetectable in spots 1 and 2, and was around $15 \mathrm{wt} \%$ in spot 3 . These results demonstrated the presence of pathways connecting the coating to the substrate, and aluminum oxides due to the spontaneous reactions between the electrolyte and $\mathrm{Al}$ in the wetted zone. Even after $2200 \mathrm{~h}$ of immersion, no coating 


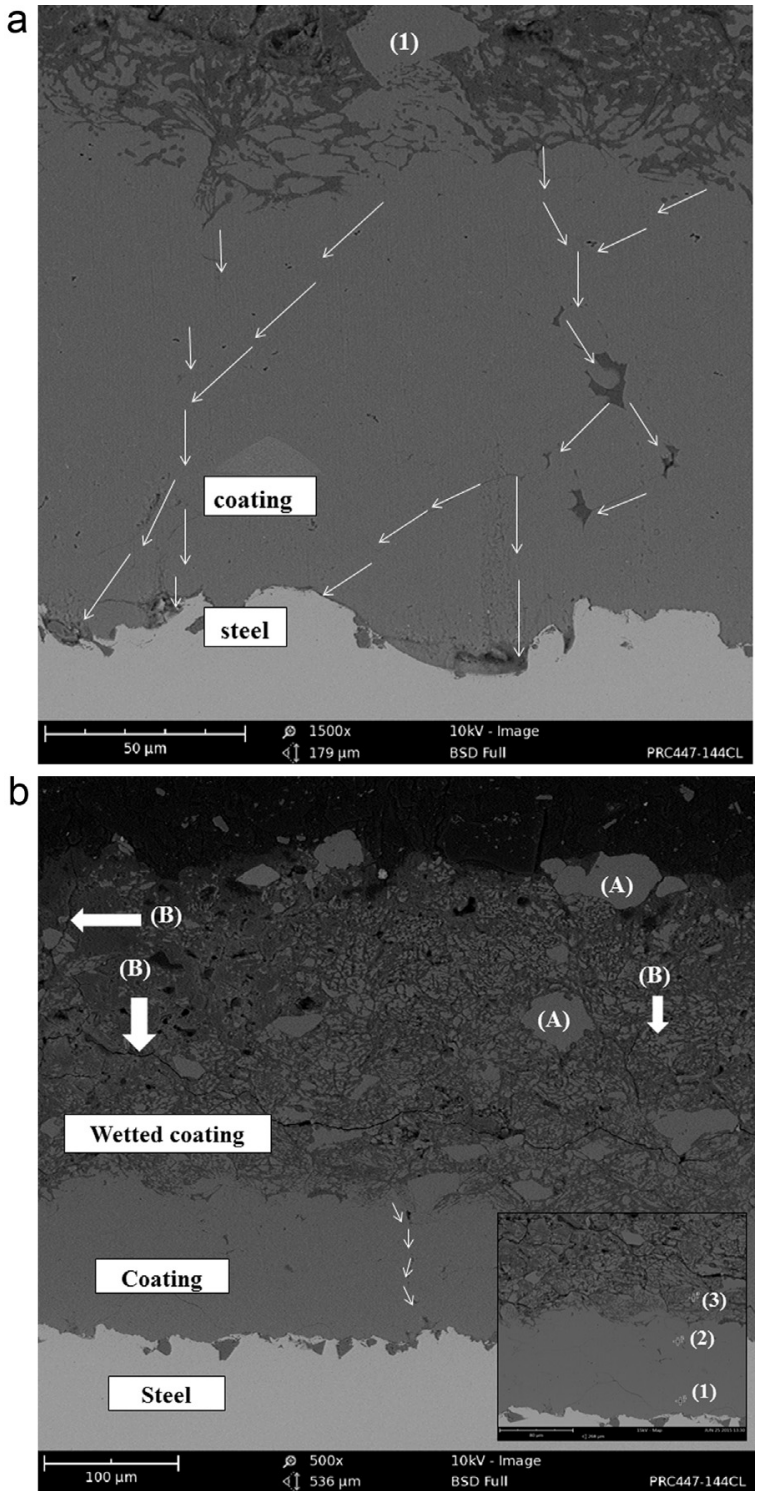

Fig. 8. Cross section SEM images of $\mathrm{Al} /$ grit blasted steel after $2200 \mathrm{~h}$ in $3.5 \mathrm{wt} \% \mathrm{NaCl}$ : (a) and (b) different regions and amplifications. Insert indicates the spots where EDS was performed.

delamination was observed, as it can be seen in Figs. 8a, b and 7S (Supplementary data), where different regions of the $\mathrm{Al} /$ grit blasted steel have demonstrated the damage evolution of the cross section with the immersion time, while the coating/steel interface was still preserved.

\subsubsection{Electrochemical impedance studies}

EIS measurements performed with the steel substrate (Fig. 9, at $1 \mathrm{~h}$ of immersion) showed one semicircle in the complex plane plot and one time constant (for short immersion times, at 1 and $4 \mathrm{~h}$ in $\mathrm{NaCl}$ solution) at medium frequency range (MF) identified from Bode phase angle plot. For $4<\mathrm{t} \leq 160 \mathrm{~h}$, the complex plane plots show one semicircle with a decreasing of the real impedance at low frequencies (Fig. 9(a)). This decreasing suggests ions desorption and/or dissolution of a non-protective film. The Bode phase plot (Fig. 9(b)) shows one time constant at medium frequency (MF) with a phase angle at $\sim 2.5 \mathrm{~Hz}\left(\sim-70^{\circ}\right)$ and another relaxation time at low frequency, corresponding to desorption/dissolution of iron species. Accordingly, the modulus of impedance was the lowest and decreased at low frequency (LF) region (Fig. 9(b)). The cathodic
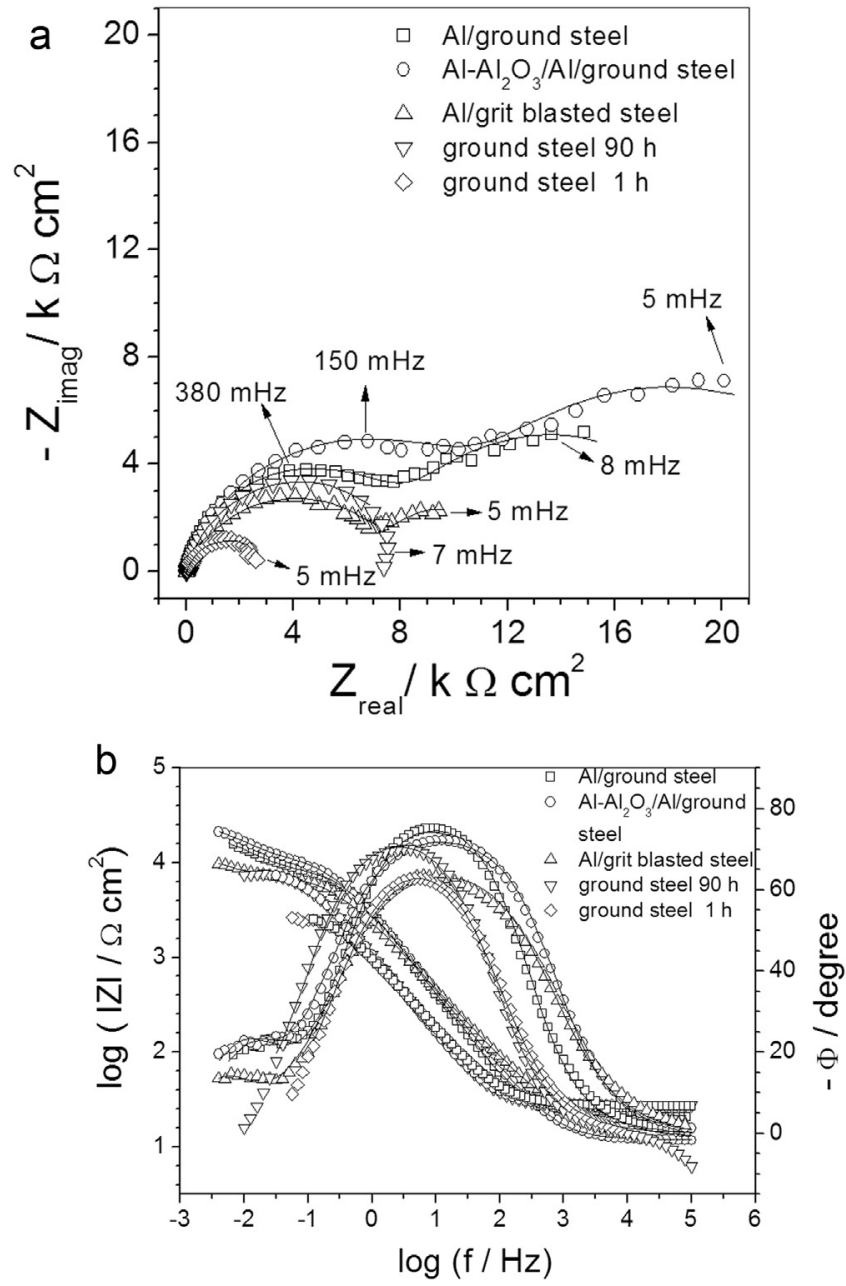

Fig. 9. (a) Experimental (symbol) and fitting (solid line) complex plane and (b) Bode phase plots obtained for the substrate ( 2 and $90 \mathrm{~h}$ ) and coated samples for $90 \mathrm{~h}$ of immersion in $3.5 \mathrm{wt} \% \mathrm{NaCl}$ solution at $25^{\circ} \mathrm{C}$.

reaction is mainly represented by eqn. (8) as previously described for iron in the same electrolyte and under similar conditions [31].

Figs. 9 and 10 show EIS diagrams that illustrate the impedance behavior of the Al-based coatings in chloride solution at different immersion times. EIS diagrams for each coating (more than 60 diagrams) were obtained during the time course of immersion, but two immersion times were chosen as representative of the set of experiments, one after $90 \mathrm{~h}$ and other after longer immersion time $(600 \mathrm{~h})$, to illustrate the EIS diagrams, and Figs. 8S-10S (Supplementary data) illustrates the evolution of the impedance diagrams with the immersion time for the three studied coatings. In Figs. 9 and 10 the solid lines correspond to the fitting results of the impedance data.

For the aluminum-based coatings and at around $90 \mathrm{~h}$ and $600 \mathrm{~h}$ of immersion, the Nyquist plots (Fig. 9(a) and Fig. 10(a)) showed at least two separated semicircles. At $90 \mathrm{~h}$ the amplitudes of the semicircles followed the order: $\mathrm{Al}-\mathrm{Al}_{2} \mathrm{O}_{3} / \mathrm{Al} /$ ground steel $>\mathrm{Al}$ /ground steel $>\mathrm{Al} /$ grit blasted steel. Accordingly, the $\mathrm{Al}$ composite (reinforced) coating showed the highest modulus of impedance (Fig. 9(b)), suggesting that the addition of $\mathrm{Al}_{2} \mathrm{O}_{3}$ particles has decreased the exposed area of $\mathrm{Al}$ in the reinforced sample. At $600 \mathrm{~h}$ the amplitudes of the semicircles followed the order: $\mathrm{Al} /$ ground steel $>\mathrm{Al} /$ grit blasted steel $>$ reinforced coating. This result suggests that the attack around the $\mathrm{Al}_{2} \mathrm{O}_{3}$ particles with the increase of immersion time decreased its corrosion resistance, agreeing with [31]. Therefore, at longer immersion times, the high mechanical resistance is the main benefit of the addition of alumina 

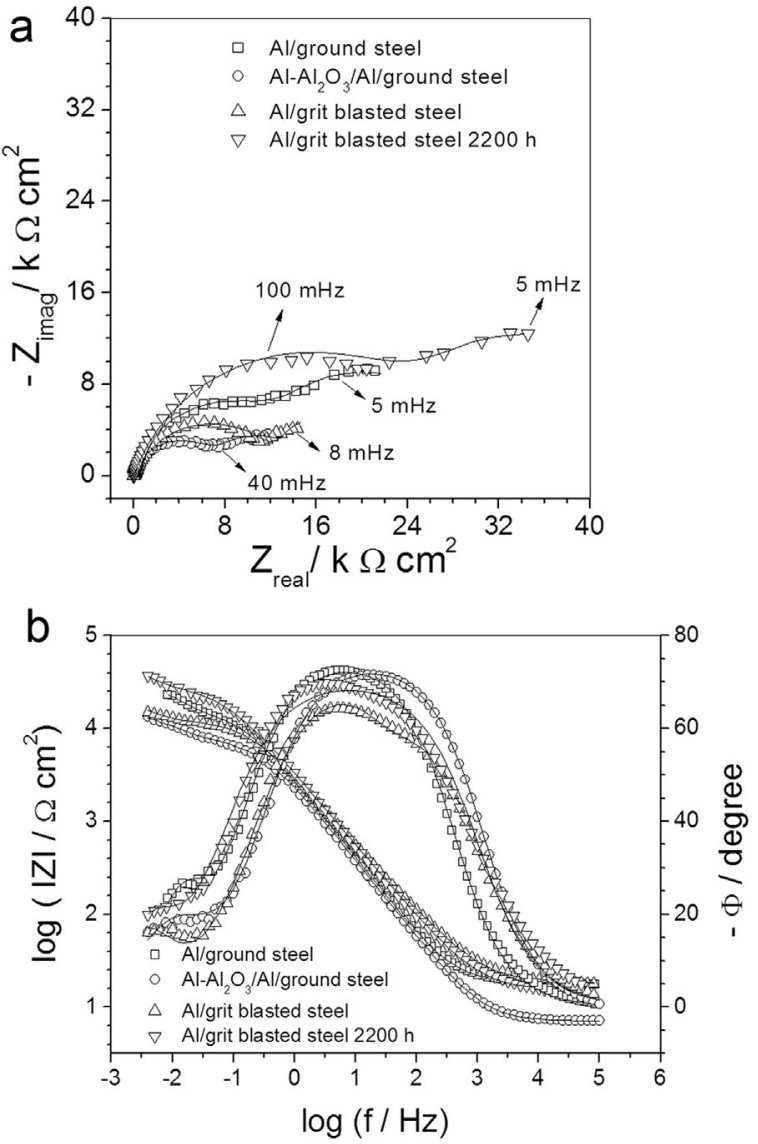

Fig. 10. (a) Experimental (symbol) and fitting (solid line) complex plane and (b) Bode phase plots obtained for coated samples for $600 \mathrm{~h}$ of immersion in $3.5 \mathrm{wt} \%$ $\mathrm{NaCl}$ solution at $25^{\circ} \mathrm{C}$.

particles to the $\mathrm{Al}$ coating. It is to be noted that no iron dissolution was observed for experiments performed at around $600 \mathrm{~h}$ of immersion as can be seen the integrity of the substrate in Fig. 7. However, differently of the other coatings, the impedance of $\mathrm{Al} /$ grit blasted steel sample continuous to increase with the immersion time (Fig. 10(a), curve for $2200 \mathrm{~h}$ ), indicating an improving in the anti-corrosion performance. This can be due to the accumulation of corrosion products around the particles of the deposited ( $\mathrm{Al}$ and $\mathrm{Al}_{2} \mathrm{O}_{3}$ at longer times) and on the coating/substrate interface, slowing the corrosion process [58].

It is interesting to note that inductive loop was not observed for all coatings studied indicating that the strong adsorption of chloride on the aluminum oxide surface produced a large capacitive semicircle impeding the inductive loop to be observed at HF-MF region, in agreement with the previously work [59]. EDS microanalysis showed no chloride on the cross section of all the coated studied samples, suggesting that if some aluminum hydroxyl chloride is formed it dissolves leaving free the chloride ions in solution.

For the $\mathrm{Al} /$ and $\mathrm{Al}-\mathrm{Al}_{2} \mathrm{O}_{3} / \mathrm{Al}$ coatings, the Bode phase diagrams at the $\mathrm{MF}$ region seem to be symmetric, suggesting the presence of one time constant, but they differ each other by a slightly higher phase angle and larger frequency region for the time constant of the reinforced sample, which means higher capacitive behavior. Brett $[60,61]$ has assigned the time constant at higher frequency to the oxide formation at the $\mathrm{Al} /$ oxide interface ( $\mathrm{Al}$ is oxidized first to $\mathrm{Al}^{+}$at that interface and then to $\mathrm{Al}^{3+}$ at the film/solution interface). On other hand, Lenderink et al. [62] and Frers et al. [63] attributed this time constant to the oxide layer itself. EDS microanalysis of the $\mathrm{Al}$ powder and $\mathrm{Al} /$ ground steel sample showed around 3 and $5 \mathrm{wt} \% \mathrm{O}_{2}$, respectively, and therefore it could be attributed the time constant at higher frequency to oxide itself. Coherently, for $\mathrm{Al}-\mathrm{Al}_{2} \mathrm{O}_{3} / \mathrm{Al} /$ ground steel coating, the time constant at higher frequency region could also be attributed to the aluminum oxide. However, when a film of solution containing $1 \%$ Aluminon $\left(\mathrm{C}_{22} \mathrm{H}_{23} \mathrm{~N}_{3} \mathrm{O}_{9}\right.$, triammonium salt of aurin tricarboxylic acid) covered the surface of the Al-based samples, spots of red color were observed after 3 or $7 \mathrm{~h}$ of immersion (Fig. 11S, Supplementary data). It means that $\mathrm{Al}^{3+}$ ions are freely formed in solution; therefore, it should be considered that $\mathrm{Al}$ is easy oxidized at potentials around the open circuit potential in $\mathrm{NaCl}$ solution. Therefore, the time constant at higher frequency range may be related to one process (oxide film itself) or to two processes (oxide film itself and aluminum oxidation) observed as a result of the complete overlapped of the two time constants. This last assumption was assumed in this work.

On the other hand, the $\mathrm{Al} /$ grit blasted steel sample shows an asymmetric Bode phase diagram (Figs. 9 b, 10 b and 10Sb), suggesting the presence of two partially overlapped time constants in the same frequency region described above for the other coatings. The nature of this two time constants may be related to the oxide film itself and aluminum oxidation. The reason for these two partially separated time constants appear for $\mathrm{Al} /$ grit blasted and not for the other samples is not clear yet and needs further investigation. The phase angle increases from $-61^{\circ}$ to $-70^{\circ}$ at the first $\mathrm{h}$ and $2200 \mathrm{~h}$ of immersion and slightly shifts to lower frequency, suggesting a small increase of the capacitive behavior.

All Al-based coatings have also shown one time constant for frequencies below $0.1 \mathrm{~Hz}$, which has been assigned to the aluminum oxide dissolution in accordance with the literature [62,63]. For $\mathrm{Al} /$ grit blasted steel sample and times of $2200 \mathrm{~h}$, it was observed that the coating failed, and led to the substrate oxidation at small regions of the coating/substrate interface, as shown in Fig. 8 (see also Fig. 7S, Supplementary material, where one can see regions of the coating/substrate interface that were not attacked).

The modulus of impedance at low frequency (Figs. $9 \mathrm{~b}, 10 \mathrm{~b}$ and 10Sb) showed different behavior for all coatings: (a) for Al/ground steel slightly decreased up to $98 \mathrm{~h}$, then increased up to $312 \mathrm{~h}$, decreased again at $445 \mathrm{~h}$ and maintained constant until the end of the test in a higher value compared to the initial one; (b) for Al$\mathrm{Al}_{2} \mathrm{O}_{3} / \mathrm{Al} /$ ground steel decreased in the first $24 \mathrm{~h}$, then increased up to $440 \mathrm{~h}$, decreased abruptly at $547 \mathrm{~h}$, and slightly increased at the end of the experiment, but with a value lower than the initial one. It is clearly related to the attack around the alumina particles; (c) for $\mathrm{Al} /$ grit blasted the values were always higher than the initial one, but were to up and down until $96 \mathrm{~h}$, and then increased until the end of the test, $2200 \mathrm{~h}$ of immersion. It could suggest that the attack on the small areas of the substrate has led to blocking the iron oxidation by the local precipitation of corrosion products.

For all samples the modulus of impedance values at low frequency region $(<0.1 \mathrm{~Hz})$ tended to increase as the frequency decreased, suggesting some contribution of diffusion, similarly to what was observed in the literature [64].

The qualitative observations were corroborated by the quantitative interpretation of the EIS data obtained for the substrate and coated samples at different immersion times by fitting the electrical equivalent circuit (EEC) shown in Fig. 11. The values of the elements of the EECs are shown in Table $2 \mathrm{~S}$ (Supplementary data). For the experiments with the steel substrate $R_{\mathrm{S}}$ was $26 \Omega \mathrm{cm}^{2}$ independent of time and for the coatings was $21 \Omega \mathrm{cm}^{2}$, which can be considered similar, as expected. For the substrate, the EEC of Fig. 11(a) fitted the EIS diagrams for the first $4 \mathrm{~h}$ of immersion and the EEC of Fig. 11(b) fits EIS diagrams obtained for longer immersion times. The first time constant $C P E_{\mathrm{dl}} / / R_{\mathrm{ct}}$ at $\mathrm{MF}$ is attributed to iron oxidation and oxygen reduction, being $C P E_{\mathrm{dl}}$ related to the capacitance of the electrical double layer, and $R_{\mathrm{ct}}$ the charge transfer resistance. $C P E_{\mathrm{dl}}$ is constituted by the coefficient $C P E_{\mathrm{dl}}-\mathrm{T}$ and the exponent $n_{\mathrm{dl}}$. At low 
a

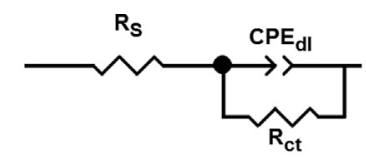

Ground steel - time $\leq 4 \mathrm{~h}$
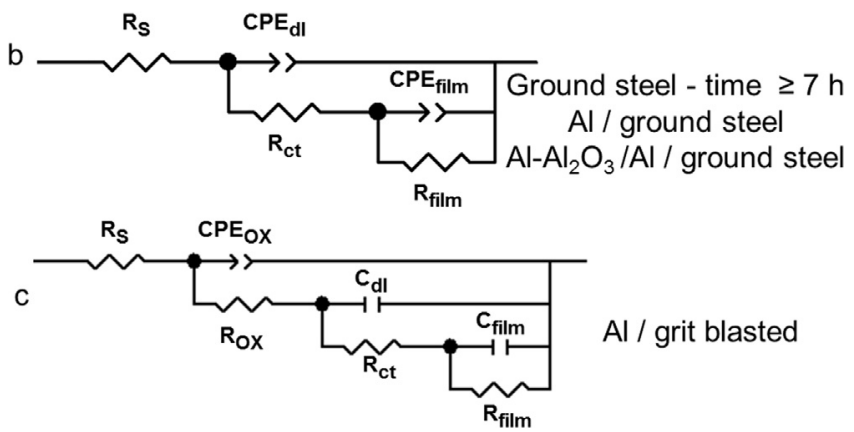

Fig. 11. Electrical equivalent circuits used to fit the EIS data. a) Steel for $t<4 \mathrm{~h}$ of immersion, b) EECs for steel and $\mathrm{Al} /$ ground steel and $\mathrm{Al}^{-} \mathrm{Al}_{2} \mathrm{O}_{3} / \mathrm{Al} /$ ground steel obtained for longer immersion times, and c) EEC to fit data obtained for $\mathrm{Al} /$ grit blasted steel at different immersion times. For $\mathrm{Al} /$ ground steel and $\mathrm{Al}$ $\mathrm{Al}_{2} \mathrm{O}_{3} / \mathrm{Al} /$ ground steel samples, the $R_{\mathrm{ct}}$ in the EEC represents the contribution of $R_{\mathrm{OX}}+R_{\mathrm{ct}}$

frequency (LF) the $C P E_{\text {film }} / R_{\text {film }}$ sub-circuit is related to iron ions desorption and non-protective film formation/dissolution, where $C P E_{\text {film }}$ is related to the capacitance of the film (adsorbed species and iron oxides-hydroxides) and $R_{\text {film }}$ the resistance of the film and solution inside the pores and defects of the film. It is possible that some iron oxide is formed during the surface preparation; however, its influence in such aggressive chloride solution is negligible. Similarly, $C P E_{\text {film }}$ has two components $C P E_{\text {film }}-T$ and $n_{\text {film. }}$. When $0.5<n<1$ the deviation from the ideal behavior is associated to a heterogeneous, rough or non-homogeneous current distribution on the electrode surface [65-68], or either to a non-homogeneous distribution of the electrical properties within the oxide film [69,70], while $n=1$ corresponds to a capacitor and 0.5 to a diffusion process at low frequencies or porous electrode response at high frequencies. Zhu et al. [13] also used CPE instead of capacitor (C) to analyze the impedance data obtained with coatings prepared by CS technology. In the circuit, the capacitor was substituted for a CPE to consider the non-ideality of the system [71].

For $\mathrm{Al} /$ ground steel and $\mathrm{Al}-\mathrm{Al}_{2} \mathrm{O}_{3} / \mathrm{Al} /$ ground steel samples, the EEC of Fig. 11b fitted well the experimental data like that previously suggested [13] for CGS aluminum coatings. As mentioned in the qualitative discussion of the Bode phase diagrams, the time constant at higher frequency may be resulted of two completely overlapped time constants: one attributed to the aluminum oxide itself $[62,63]$ and the other to aluminum oxidation $[60,61]$ and the time constant at low frequency region $(<0.1 \mathrm{~Hz})$ was attributed to the oxide film dissolution/diffusion through a barrier oxide layer [64]. In the electrochemical corrosion of coated steel, the diffusion of $\mathrm{Cl}^{-}$or other reactant is microscopically confined within pores or grain boundaries [72], therefore, the structure of Al coating may influence the diffusion behavior. To fit the data obtained for $\mathrm{Al} /$ grit blasted steel, the time constant attributed to the aluminum oxide itself and aluminum oxidation are partially overlapped and the data were described by the EEC showed on Fig. 11c, being the time constant denoted by $C P E_{\mathrm{OX}} / / R_{\mathrm{OX}}$.

The suitability of the proposed EECs was indicated by the sum of Chi-squared deviations $\left(\chi^{2}\right)$ value around $10^{-4}$ with relative low standard errors $(<10 \%)$ of each parameter (see Table 2 S, Supplementary data), as well as the good agreement between the fitted and experimental EIS diagrams (Figs. 9 and 10). As mentioned above, $\mathrm{Al} /$ ground steel and $\mathrm{Al}-\mathrm{Al}_{2} \mathrm{O}_{3} / \mathrm{Al} /$ ground steel samples showed two time constants, one at higher frequency and one at lower frequency regions, while for the $\mathrm{Al} /$ grit blasted steel sample three time con- stants were observed being two in the higher frequency region, where the first time constant is located for the other coatings. Thus, the first time constant for $\mathrm{Al} /$ ground steel and $\mathrm{Al}-\mathrm{Al}_{2} \mathrm{O}_{3} / \mathrm{Al} /$ ground steel samples are supposed to result from a contribution of both aluminum oxide and aluminum oxidation $\left(R_{\mathrm{OX}}+R_{\mathrm{ct}}\right)$ and then the sum $\left(R_{\mathrm{OX}}+R_{\mathrm{ct}}\right)$ versus immersion time is represented for the three aluminum-based coatings. Fig. 12 shows the evolution of (a) $\left(R_{\mathrm{OX}}+R_{\mathrm{ct}}\right)$ and (b) $R_{\mathrm{film}}$ for all coatings, and (c) $R_{\mathrm{OX}}$ for $\mathrm{Al} /$ grit blasted steel coating in $3.5 \% \mathrm{NaCl}$ solution at $25^{\circ} \mathrm{C}$.

The $\left(R_{\mathrm{OX}}+R_{\mathrm{ct}}\right)$ resistance for $\mathrm{Al} /$ ground steel was around $10 \mathrm{k} \Omega \mathrm{cm}^{2}$ at the first $20 \mathrm{~h}$ of immersion, decreased and stabilized at $\sim 7.5 \mathrm{k} \Omega \mathrm{cm}^{2}$ up to $\sim 180 \mathrm{~h}$, and increased up to $\sim 17 \mathrm{k} \Omega \mathrm{cm}^{2}$ at $220 \mathrm{~h}$, and then stabilized around this value until the end of the experiment (Fig. 12(a) and Table 2S). The higher initial values were associated with the presence of the natural and defective oxide layer that was formed on the as-prepared surface of the samples. This oxide was attacked by the electrolyte exposing the more active Al coating, and the resistance has decreased, but as time went by the product of the hydrolysis of aluminum ions might accumulate on the active regions, leading to an increase of the $\left(R_{\mathrm{OX}}+R_{\mathrm{Ct}}\right)$ values.

For $\mathrm{Al}-\mathrm{Al}_{2} \mathrm{O}_{3} / \mathrm{Al} /$ ground steel coating $\left(R_{\mathrm{OX}}+R_{\mathrm{ct}}\right)$ resistance has slightly increased from 6 to $9.5 \mathrm{k} \Omega \mathrm{cm}^{2}$ up to $50 \mathrm{~h}$ of immersion, has stabilized at around $(12 \pm 3) \mathrm{k} \Omega \mathrm{cm}^{2}$ until $170 \mathrm{~h}$, has increased to $(18 \pm 4) \mathrm{k} \Omega \mathrm{cm}^{2} 440 \mathrm{~h}$, then abruptly decreased to $\sim 2 \mathrm{k} \Omega \mathrm{cm}^{2}$ at $532 \mathrm{~h}$, has varied from 0.2 to $5.6 \mathrm{k} \Omega \mathrm{cm}^{2}$ until $550 \mathrm{~h}$ and assumed the value of $\sim 12 \mathrm{k} \Omega \mathrm{cm}^{2}$ up to $650 \mathrm{~h}$ (see Table $2 \mathrm{~S}$ ). The increase of $\left(R_{\mathrm{OX}}+R_{\mathrm{ct}}\right)$ resistance at short immersion times could be related to the oxide formation by the reaction of water with aluminum, increasing the area covered by aluminum oxide, but chloride begun attacking the defected aluminum oxide around alumina particles forming local cells, as observed by the SEM images (Fig. 7(b)). For long times these local cells accelerated the aluminum dissolution leading to a rapid decreasing of the $\left(R_{\mathrm{OX}}+R_{\mathrm{ct}}\right)$ resistance. The local cells were probably maintained active up to around $650 \mathrm{~h}$, when the products of the hydrolysis of aluminum ions diminished the active areas, leading to increasing the resistance.

For $\mathrm{Al} /$ grit blasted steel $\left(R_{\mathrm{OX}}+R_{\mathrm{ct}}\right)$ resistance was around $8 \mathrm{k} \Omega \mathrm{cm}^{2}$ at the initial times, varied from 6 to $8 \mathrm{k} \Omega \mathrm{cm}^{2}$ up to $\sim 340 \mathrm{~h}$, increased to $14 \mathrm{k} \Omega \mathrm{cm}^{2}$ at around $430 \mathrm{~h}$, decreased to around $9 \mathrm{k} \Omega \mathrm{cm}^{2}$ between 480 and $570 \mathrm{~h}$, stabilized at around $18 \mathrm{k} \Omega \mathrm{cm}^{2}$ until $\sim 1050 \mathrm{~h}$, and then increased to $28 \mathrm{k} \Omega \mathrm{cm}^{2}$ at 1400 and $2200 \mathrm{~h}$ of immersion. The explanation for the variation of the $\left(R_{\mathrm{OX}}+R_{\mathrm{ct}}\right)$ until $1050 \mathrm{~h}$ is the same given above for the other coatings. However, the increase of $\left(R_{\mathrm{OX}}+R_{\mathrm{ct}}\right)$ to $28 \mathrm{k} \Omega \mathrm{cm}^{2}$ can be attributed to the blocking of the pores by the corrosion products including iron and aluminum oxides (Fig. 8(b)).

For $\mathrm{Al} /$ ground steel, the resistance for the film dissolution $\left(R_{\mathrm{film}}\right)$ increased from 3 to $15 \mathrm{k} \Omega \mathrm{cm}^{2}$ in the first $20 \mathrm{~h}$, maintained around $12 \mathrm{k} \Omega \mathrm{cm}^{2}$ up to $50 \mathrm{~h}$, slightly decreased to $3.8 \mathrm{k} \Omega \mathrm{cm}^{2}$ at $165 \mathrm{~h}$, then increased to $40 \mathrm{k} \Omega \mathrm{cm}^{2}$ until $\sim 300 \mathrm{~h}$, followed by decreasing to $\sim 18 \mathrm{k} \Omega \mathrm{cm}^{2}$ at $370 \mathrm{~h}$ and then maintained around this value up to $706 \mathrm{~h}$. The increase of this resistance at the initial can be associated with the increase of the film thickness and the decreased could be due to the increase of the porosity of the film mainly around the non-dissolved aluminum particles, and the blocking of these pores by the corrosion products could be responsible by the following increasing of the resistance of the film dissolution. After $370 \mathrm{~h}$ the film seems to have reached a condition where the impedance of the film does not change anymore.

For $\mathrm{Al}-\mathrm{Al}_{2} \mathrm{O}_{3} / \mathrm{Al} /$ ground steel, the $R_{\text {film }}$ values increased from 1.3 to $8.2 \mathrm{k} \Omega \mathrm{cm}^{2}$ during the first $15 \mathrm{~h}$, decreased to $4 \mathrm{k} \Omega \mathrm{cm}^{2}$ until $21 \mathrm{~h}$, varied around $12 \mathrm{k} \Omega \mathrm{cm}^{2}$ until $67 \mathrm{~h}$, and a little higher until $368 \mathrm{~h}$, increased to $30 \mathrm{k} \Omega \mathrm{cm}^{2}$ until $440 \mathrm{~h}$ and then sharply decreased to very low values up to the end of experiment (Table $2 S$ ). At the beginning the behavior was like the $\mathrm{Al} /$ ground steel sample with the same explanation; however, after $440 \mathrm{~h}$ the oxide film seems 

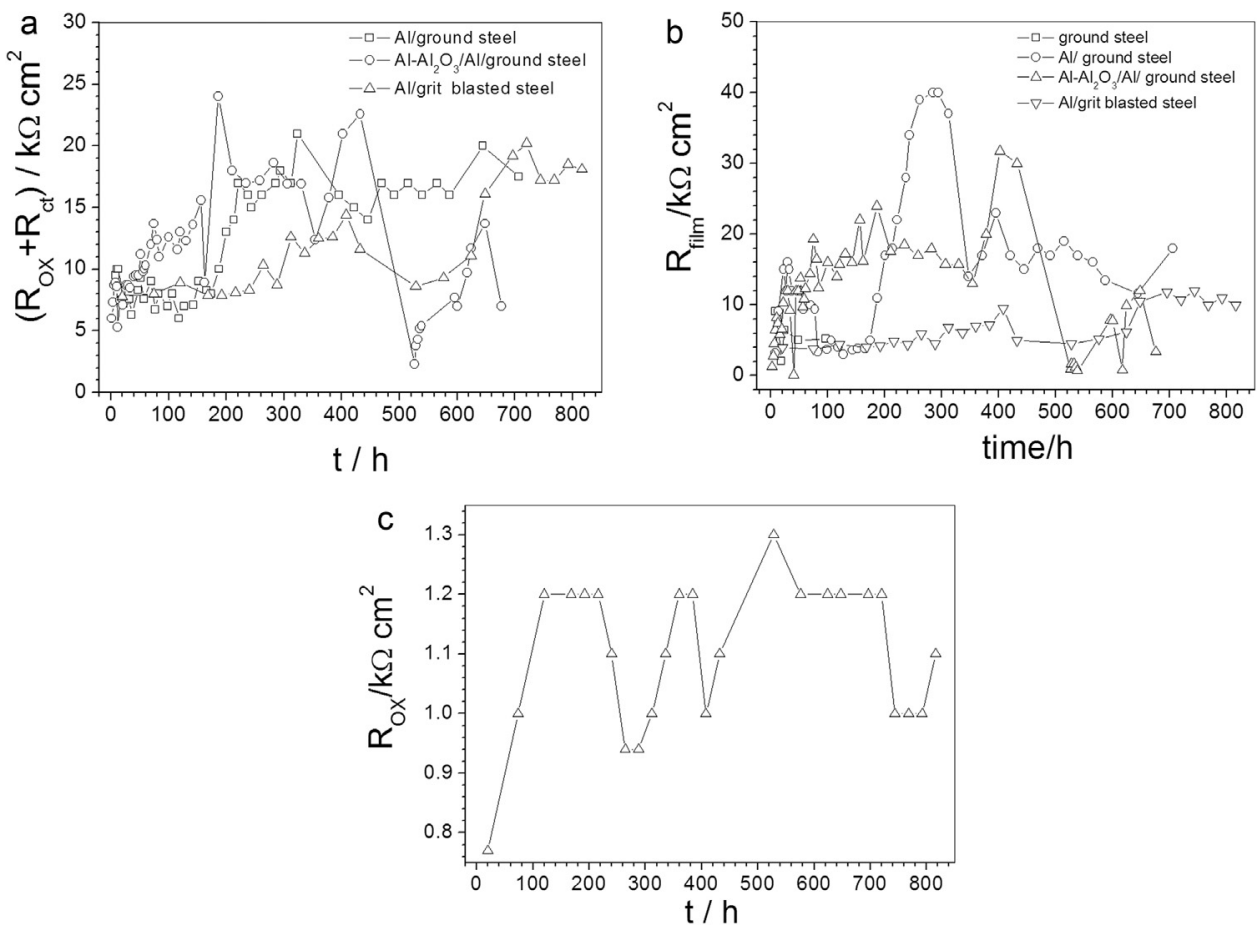

Fig. 12. (a) $\left(R_{\mathrm{OX}}+R_{\mathrm{ct}}\right)$ and (b) $R_{\mathrm{film}}$ for $\mathrm{Al}$ and $\mathrm{Al}-\mathrm{Al}_{2} \mathrm{O}_{3}$ based coatings, and (c) $R_{\mathrm{OX}}$ for $\mathrm{Al} /$ grit blasted steel coating versus immersion time in $3.5 \% \mathrm{NaCl}$ solution at $25{ }^{\circ} \mathrm{C}$.

to be easily dissolved, probably due to the local cells caused by the preferential attack to around the alumina particles as shown in Fig. 7(b).

For $\mathrm{Al} /$ grit blasted steel the resistance of the film dissolution was around $5 \mathrm{k} \Omega \mathrm{cm}^{2}$ up to around $600 \mathrm{~h}$ and then stabilized at $\sim 11 \mathrm{k} \Omega \mathrm{cm}^{2}$ (Table 2S). Comparing the $R_{\text {film }}$ values for short immersion times $(\sim 150 \mathrm{~h})$ the following order is provided: $\mathrm{Al}-\mathrm{Al}_{2} \mathrm{O}_{3} / \mathrm{Al} /$ ground steel $>\mathrm{Al} /$ ground steel $\approx \mathrm{Al} /$ grit blasted steel, and for longer times $(\sim 700 \mathrm{~h}): \mathrm{Al} /$ grit blasted steel $\approx \mathrm{Al} /$ ground steel $>\mathrm{Al}-\mathrm{Al}_{2} \mathrm{O}_{3} / \mathrm{Al} /$ ground steel. $R_{\mathrm{OX}}$ (Fig. $12(\mathrm{c})$ ) for $\mathrm{Al} /$ grit blasted steel was $\sim 1.1 \mathrm{k} \Omega \mathrm{cm}^{2}$ for the major part of experiments, indicating no significant influence of the immersion time (Table $2 \mathrm{~S}$ ).

The virtually stabilization of the resistance of the coatings at the intermediated immersion times was also observed previously by TAO et al. [28] and ZHU et al. [13] and was attributed to the occupation of areas between the splats by corrosion products. These results indicated that the addition of $\mathrm{Al}_{2} \mathrm{O}_{3}$ could increase the corrosion resistance below $450 \mathrm{~h}$, however the corrosion of $\mathrm{Al}$ around the alumina particles dominated the global process for longer times, and the corrosion resistance depends on the substrate preparation. Therefore, the resistance behavior observed for relatively short times agree with $[73,74]$, but this increase reflects the decrease in active area resulting in a current density decreasing, while those obtained for longer immersion times agree with $[23,25]$, in which the addition of alumina did not improve the corrosion resistance.

\section{Conclusions}

1. Coatings of $\mathrm{Al}$ and $\mathrm{Al}-\mathrm{Al}_{2} \mathrm{O}_{3} / \mathrm{Al}$ composite applied on ground or grit blasted steel substrates with low porosity $(<0.8 \%)$, good adhesion (25-30 MPa) and thickness $>300 \mu \mathrm{m}$ were successfully prepared by cold spray technology.

2. Mechanical properties of the coatings surface were improved by the addition of alumina particles into the outer layer of the coating.

3. All the studied Al-based coatings have protected the substrate against corrosion for a long time such as $3000 \mathrm{~h}$ in salt fog tests.

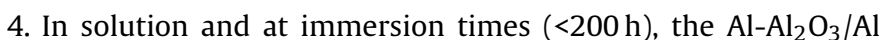
composite coating showed higher corrosion resistance, probably due to the lower active area of $\mathrm{Al}$, and it showed lower corrosion performance for immersion times higher than $200 \mathrm{~h}$ due to the severe corrosion of $\mathrm{Al}$ matrix surrounding the alumina particles. For immersion time higher than around $600 \mathrm{~h}$, the $\mathrm{Al} /$ grit blasted steel showed the highest corrosion performance.

5. The detection of aluminum ions in the solution (Aluminon test) at around $1 \mathrm{~h}$ of immersion indicates that $\mathrm{Al}$ is easily oxidized; however, the coating/substrate interface was not corroded up to $1200 \mathrm{~h}$ of immersion, and for the $\mathrm{Al} /$ grit blasted steel some spots of corrosion were observed at the coating/substrate interface after $2200 \mathrm{~h}$ of immersion, indicating that Al-based coatings can protect steel against corrosion for a long immersion time.

\section{Acknowledgements}

The authors would like to thank the Ministerio de Ciencia y Tecnología (Proyecto MAT2009-10827), to the Generalitat de Catalunya (Proyecto 2009SGR390) by the financial support, to the CNPq - Conselho Nacional de Pesquisa (Procs. 153177/2014-4 and 201325/2014-4) for the financial support and scholarships, and to CEMPEQC (Centro de Monitoramento e Pesquisa da Qualidade de Combustíveis, Biocombustíveis, Petróleo e Derivados) for the analysis of low carbon steel.

\section{Appendix A. Supplementary data}

Supplementary data associated with this article can be found, in the online version, at http://dx.doi.org/10.1016/j.corsci.2016.10. 019.

\section{References}

[1] N. Bala, H. Singh, J. Mater Des Karthikeyan, S. Prakash, Cold spray coating process for corrosion protection: a review, Surf. Eng. 30 (2014) 414-421, http://dx.doi.org/10.1179/1743294413Y.0000000148. 
[2] A. Moridi, S.M. Hassani-Gangaraj, M. Guagliano, M. Dao, Cold spray coating: review of material systems and future perspectives, Surf. Eng. 30 (2014) 369-395, http://dx.doi.org/10.1179/1743294414Y.0000000270.

[3] H. Assadi, F. Gärtner, T. Stoltenhoff, H. Kreye, Bonding mechanism in cold gas spraying, Acta Mater. 51 (2003) 4379-4394, http://dx.doi.org/10.1016/S13596454(03)00274-X.

[4] W.-Y. Li, H. Liao, G. Douchy, C. Coddet, Optimal design of a cold spray nozzle by numerical analysis of particle velocity and experimental validation with 316L stainless steel powder, Mater. Des. 28 (2007) 2129-2137, http://dx.doi. org/10.1016/j.matdes.2006.05.016.

[5] J. Pattison, S. Celotto, A. Khan, W. O'Neill, Standoff distance and bow shock phenomena in the Cold Spray process, Surf. Coat. Technol. 202 (2008) 1443-1454, http://dx.doi.org/10.1016/j.surfcoat.2007.06.065.

[6] H. Lee, H. Shin, S. Lee, K. Ko, Effect of gas pressure on Al coatings by cold gas dynamic spray, Mater. Lett. 62 (2008) 1579-1581, http://dx.doi.org/10.1016/j. matlet.2007.09.026.

[7] M.M. Sharma, T.J. Eden, B.T. Golesich, Effect of surface preparation on the microstructure, adhesion, and tensile properties of cold-sprayed aluminum coatings on AA2024 substrates, J. Therm. Spray Technol. 24 (2014) 410-422, http://dx.doi.org/10.1007/s11666-014-0175-1.

[8] G. Goupil, S. Jucken, D. Poirier, J.G. Legoux, E. Irissou, B. Davis, D.L. Guay. Roué, Cold sprayed $\mathrm{Cu}-\mathrm{Ni}-\mathrm{Fe}$ anode for Al production, Corros. Sci. 90 (2015) 259-265 http://dx.doi.org/10.1016/j.corsci.2014.10.021.

[9] B. Jodoin, L. Ajdelsztajn, E. Sansoucy, A. Zúñiga, P. Richer, E.J. Lavernia, Effect of particle size, morphology, and hardness on cold gas dynamic sprayed aluminum alloy coatings, Surf. Coat. Technol. 201 (2006) 3422-3429, http:// dx.doi.org/10.1016/j.surfcoat.2006.07.232.

[10] S. Dosta, M. Couto, J.M. Guilemany, Cold spray deposition of a WC-25Co cermet onto Al7075-T6 and carbon steel substrates, Acta Mater. 61 (2013) 643-652, http://dx.doi.org/10.1016/j.actamat.2012.10.011.

[11] V. Crespo, I.G. Cano, S. Dosta, J.M. Guilemany, The influence of feedstock powders on the CGS deposition efficiency of bond coats for TBCs, J. Alloys Compd. 622 (2015) 394-401, http://dx.doi.org/10.1016/j.jallcom.2014.09.216.

[12] N. Cinca, E. López, S. Dosta, J.M. Guilemany, Study of stellite-6 deposition by cold gas spraying, Surf. Coat Technol. 232 (2013) 891-898, http://dx.doi.org/ 10.1016/j.surfcoat.2013.06.120.

[13] Q.J. Zhu, K. Wang, X.H. Wang, B.R. Hou, Electrochemical impedance spectroscopy analysis of cold sprayed and arc sprayed aluminium coatings serviced in marine environment, Surf. Eng. 28 (2012) 300-305, http://dx.doi. org/10.1179/1743294411Y.0000000036.

[14] S. Grigoriev, A. Okunkova, A. Sova, P. Bertrand, I. Smurov, Cold spraying: from process fundamentals towards advanced applications, Surf. Coat. Technol. 268 (2014) 77-84, http://dx.doi.org/10.1016/j.surfcoat.2014.09.060.

[15] M.R. Dorfman, Handbook of Environmental Degradation of Materials, William Andrew Publishing, Norwich, 2005, pp. 405-422 (ISBN: 9781437734553).

[16] H.Y. Lee, Y.H. Yu, Y.C. Lee, Y.P. Hong, K.H. Ko, Cold spray of $\mathrm{SiC}$ and $\mathrm{Al}_{2} \mathrm{O}_{3}$ with soft metal incorporation: a technical contribution, J. Therm. Spray Technol. 13 (2004) 184-189, http://dx.doi.org/10.1361/10599630419355.

[17] A.P. Sannino, H.J. Rack, Dry sliding wear of discontinuously reinforced aluminum composites: review and discussion, Wear 189 (1995) 1-19, http:// dx.doi.org/10.1016/0043-1648(95)06657-8.

[18] T. Miyajima, Y. Iwai, Effects of reinforcements on sliding wear behavior of aluminum matrix composites, Wear 255 (2003) 606-616, http://dx.doi.org/ 10.1016/S0043-1648(03)00066-8.

[19] Q. Wang, K. Spencer, N. Birbilis, M.X. Zhang, The influence of ceramic particles on bond strength of cold spray composite coatings on AZ91 alloy substrate, Surf. Coat. Technol. 205 (2010) 50-56, http://dx.doi.org/10.1016/j.surfcoat. 2010.06.008.

[20] S.A. Sajjadi, H.R. Ezatpour, H. Beygi, Microstructure and mechanical properties of $\mathrm{Al}-\mathrm{Al}_{2} \mathrm{O}_{3}$ micro and nano composites fabricated by stir casting, Mater. Sci. Eng. A 528 (2011) 8765-8771, http://dx.doi.org/10.1016/j.msea.2011.08.052.

[21] B. Ralph, H.C. Yuen, W.B. Lee, The processing of metal matrix composites - an overview, J. Mater. Process. Technol. 63 (1997) 339-353, http://dx.doi.org/10. 1016/S0924-0136(96)02645-3.

[22] S. Yin, X. Tao, Microstructure and mechanical properties of $\mathrm{Al} 2 \mathrm{O} 3-\mathrm{Al}$ composite coatings deposited by plasma spraying, Appl. Surf. Sci. 254 (2008) 1636-1643, http://dx.doi.org/10.1016/j.apsusc.2007.07.135.

[23] E. Irissou, J.G. Legoux, B. Arsenault, C. Moreau, Investigation of $\mathrm{Al}^{-\mathrm{Al}_{2} \mathrm{O}_{3} \text { cold }}$ spray coating formation and properties, J. Therm. Spray Technol. 16 (2007) 661-668, http://dx.doi.org/10.1007/s11666-007-9086-8.

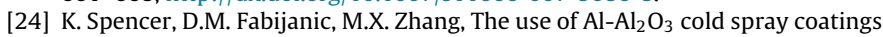
to improve the surface properties of magnesium alloys, Surf. Coat. Technol. 204 (2009) 336-344, http://dx.doi.org/10.1016/j.surfcoat.2009.07.032.

[25] Y. Tao, T. Xiong, C. Sun, H. Jin, H. Du, T. Li, Effect of $\left(-\mathrm{Al}_{2} \mathrm{O}_{3}\right.$ on the properties of cold sprayed $\mathrm{Al} /\left(-\mathrm{Al}_{2} \mathrm{O}_{3}\right.$ composite coatings on AZ91D magnesium alloy, Appl. Surf. Sci. 256 (2009) 261-266, http://dx.doi.org/10.1016/j.apsusc.2009.08.012.

[26] M.R. Rokni, C.A. Widener, V.R. Champagne, Microstructural evolution of 6061 aluminum gas-atomized powder and high-pressure cold-sprayed deposition, J. Therm. Spray Technol. 23 (2013) 514-524, http://dx.doi.org/10.1007/ s11666-013-0049y.

[27] T. Suhonen, T. Varis, S. Dosta, M. Torrell, J.M. Guilemany, Residual stress development in cold sprayed Al, Cu and Ti coatings, Acta Mater. 61 (2013) 6329-6337, http://dx.doi.org/10.1016/j.actamat.2013.06.033.

[28] Y. Tao, T. Xiong, C. Sun, L. Kong, X. Cui, T. Li, G.L. Song, Microstructure and corrosion performance of a cold sprayed aluminium coating on AZ91D magnesium alloy, Corros. Sci. 52 (2010) 3191-3197, http://dx.doi.org/10. 1016/j.corsci.2010.05.023.

[29] L. Ajdelsztajn, A. Zúñiga, B. Jodoin, E.J. Lavernia, Cold gas dynamic spraying of a high temperature Al alloy, Surf. Coat. Technol. 201 (2006) 2109-2116, http://dx.doi.org/10.1016/j.surfcoat.2005.06.001.

[30] M. Stern, A.L. Geary, Electrochemical polarization: I. A theoretical analysis of the shape of polarization curves, J. Electrochem. Soc. 104 (1957) 56-63, http://dx.doi.org/10.1149/1.2428496.

[31] E. McCafferty, Validation of corrosion rates measured by the Tafel extrapolation method, Corros. Sci. 47 (2005) 3202-3215, http://dx.doi.org/10. 1016/j.corsci.2005.05.046.

[32] K. Balani, T. Laha, A. Agarwal, J. Karthikeyan, N. Munroe, Effect of carrier gases on microstructural and electrochemical behavior of cold-sprayed 1100 aluminum coating, Surf. Coat. Technol. 195 (2005) 272-279, http://dx.doi.org/ 10.1016/j.surfcoat.2004.06.028.

[33] R.B. Heimann, J.I. Kleiman, S. Marx, R. Ng, S. Petrov, M. Shagalov, R.N.S. Sodhi, A. Tang, High-pressure cold gas dynamic (CGD) - sprayed alumina-reinforced aluminum coatings for potential application as space construction material, Surf. Coat. Technol. 252 (2014) 113-119, http://dx.doi.org/10.1016/j.surfcoat. 2014.04.053.

[34] R.M. Souto, M.M. Laz, R.L. Reis, Degradation characteristics of hydroxyapatite coatings on orthopaedic TiAlV in simulated physiological media investigated by electrochemical impedance spectroscopy, Biomaterials 24 (2003) 4213-4221, http://dx.doi.org/10.1016/S0142-9612(03)00362-4.

[35] X. Zhou, P. Mohanty, Corrosion behavior of cold sprayed titanium coatings in simulated body fluid, Corros. Eng. Sci. Technol. 47 (2012) 145-154, http://dx. doi.org/10.1179/1743278211Y.0000000037.

[36] R. Drehmann, T. Grund, T. Lampke, B. Wielage, K. Manygoats, T. Schucknecht, D. Rafaja, Splat formation and adhesion mechanisms of cold gas-sprayed al coatings on $\mathrm{Al}_{2} \mathrm{O}_{3}$ substrates, J. Therm. Spray Technol. 23 (2014) 68-75, http://dx.doi.org/10.1007/s11666-013-9966-z.

[37] H.Y. Lee, S.H. Jung, S.Y. Lee, Y.H. You, K.H. Ko, Correlation between Al2O3 particles and interface of Al-Al2O3 coatings by cold spray, Appl. Surf. Sci. 252 (2005) 1891-1898, http://dx.doi.org/10.1016/j.apsusc.2005.03.148.

[38] J.-D. Kim, S.-I. Pyun, The effects of applied potential and chloride ion on the repassivation kinetics of pure iron, Corros. Sci. 38 (1996) 1093-1102, http:/ dx.doi.org/10.1016/0010-938X(96)00004-2.

[39] J.M. Guilemany, J. Fernandez, J. Delgado, A.V. Benedetti, F. Climent, Effects of thickness coating on the electrochemical behaviour of thermal spray $\mathrm{Cr}_{3} \mathrm{C}_{2}$-NiCr coatings, Surf. Coat. Technol. 153 (2002) 107-113, http://dx.doi. org/10.1016/S0257-8972(01)01679-6.

[40] J.M. Guilemany, J. Fernández, J. Delgado, Electrochemical measurements and characterisation of a thermally sprayed HVOF $\mathrm{Cr} 3 \mathrm{C} 2$ ? NiCr coating in a corrosive environment, in: Proceedings ITSC, Düsseldorf, 1999, pp. 474-478.

[41] E. McCafferty, Sequence of steps in the pitting of aluminum by chloride ions, Corros. Sci. 45 (2003) 1421-1438, http://dx.doi.org/10.1016/S0010938X(02)00231-7.

[42] A.V. Benedetti, P.L. Cabot, J.A. Garrido, A.H. Moreira, Influence of iron addition on the microstructure and the electrochemical corrosion of $\mathrm{Al}-\mathrm{Zn}-\mathrm{Mg}$ alloys, J. Appl. Electrochem. 31 (2001) 293-300, http://dx.doi.org/10.1023/ A:1017566002951.

[43] J.V. Nardeli, D.V. Snihirova, C.S. Fugivara, M.F. Montemor, E.R.P. Pinto, Y. Messaddecq, A.V. Benedetti, Localised corrosion assessement of crambe-oil-based polyurethane coatings applied on the ASTM 1200 aluminum alloy, Corros. Sci. (2016), http://dx.doi.org/10.1016/j.corsci.2016. 05.034.

[44] J. O'M. Bockris, D.R. Drazic, A. Despic, The electrode kinetics of the deposition and dissolution of iron, Electrochim. Acta 4 (1961) 325-361, http://dx.doi.org/ 10.1016/0013-4686(61)80026-1.

[45] J. O’M. Bockris, S.U.M. Khan, Surface Electrochemistry - A Molecular Level Approach, Plenum Press, 1993, 2016, pp. 758-759 (ISBN:0-306-44339-2).

[46] E.J. Kelly, The active iron electrode I. Iron dissolution and hydrogen evolution reactions in acidic sulfate solutions, J. Electrochem. Soc. 112 (1965) 124-131, http://dx.doi.org/10.1149/1.2423480.

[47] W.J. Lorenz, Der einfluss von halogenidionen auf die anodische auflosung des eisens, Corros. Sci. 5 (1965) 121-131, http://dx.doi.org/10.1016/S0010938X(65)90478-6.

[48] E. McCafferty, N. Hackermann, Kinetics of iron corrosion in concentrated acidic chloride solutions, J. Electrochem. Soc. 119 (1972) 999-1009, http://dx. doi.org/10.1149/1.2404426.

[49] R.J. Chin, K. Nobe, Electrodissolution kinetics of iron in chloride solutions. Acidic solutions, J. Electrochem. Soc. 119 (1972) 1457-1461, http://dx.doi.org/ 10.1149/1.2404023.

[50] H.C. Kuo, K. Nobe, Electrodissolution kinetics of iron in chloride solution. VI. Concentrated acidic solutions, J. Electrochem. Soc. 125 (1978) 853-860, http://dx.doi.org/10.1149/1.2131567.

[51] F. Hilbert, Y. Miyoshi, G. Eichkorn, W.J. Lorenz, Correlations between the kinetics of electrolytic dissolution and deposition of iron. The Anodic Dissolution of Iron, J. Electrochem. Soc. 118 (1971) 1919-1926, http://dx.doi. org/10.1149/1.2407868.

[52] G.T. Burstein, D.H. Davies, The effects of anions on the behaviour of scratched iron electrodes in aqueous solutions, Corros. Sci. 20 (1980) 1143-1155, http:// dx.doi.org/10.1016/0010-938X(80)90145-6.

[53] A.S.M. International, Corrosion Understanding the Basics, ASM International, Ohio, 2000 (ISBN:978-0-87170-641-6). 
[54] S. Lameche-Djeghaba, A. Benchettara, F. Kellou, V. Ji, Electrochemical behaviour of pure aluminium and $\mathrm{Al}-5 \% \mathrm{Zn}$ alloy in $3 \% \mathrm{NaCl}$ solution, Arab. J. Sci Eng. 39 (2014) 113-122, http://dx.doi.org/10.1007/s13369-013-0876-7.

[55] El-Sayed M. Sherif, Effects of 3-amino-1,2,4-triazole-5-thiol on the inhibition of pure aluminum corrosion in aerated stagnant $3.5 \mathrm{wt} . \% \mathrm{NaCl}$ solution as a corrosion inhibitor, Int. J. Electrochem. Sci. 7 (2012) 4847-4859.

[56] T. Hagyard, J.R. Williams, Potential of aluminium in aqueous chloride solutions. Part 1, Trans. Faraday Soc. 57 (1961) 2288, http://dx.doi.org/10. 1039/tf9615702288.

[57] K.P. Wong, R.C. Alkire, Local chemistry and growth of single corrosion pits in aluminum, J. Electrochem. Soc. 137 (1990) 3010-3015, http://dx.doi.org/10. 1149/1.2086150 10.4028/www.scientific.net/MSF.111-112.565.

[58] N.M. Chavan, B. Kiran, A. Jyothirmayi, P.S. Phani, G. Sundararajan, The corrosion behavior of cold sprayed zinc coatings on mild steel substrate, J. Therm. Spray Technol. 22 (2013) 463-470, http://dx.doi.org/10.1007/s11666013-9893-Z.

[59] J.H.W. de Wit, H.J.W. Lenderink, Electrochemical impedance spectroscopy as a tool to obtain mechanistic information on the passive behaviour of aluminium, Electrochim. Acta 41 (1996) 1111-1119, http://dx.doi.org/10. 1016/0013-4686(95)00462-9.

[60] C.M.A. Brett, On the electrochemical behaviour of aluminium in acidic chloride solution, Corros. Sci. 33 (1992) 203-210, http://dx.doi.org/10.1016/ 0010-938X(92)90145-S.

[61] C.M.A. Brett, The application of electrochemical impedance techniques to aluminium corrosion in acidic chloride solution. J. Appl. Electrochem. 20 (1990) 1000-1003, http://dx.doi.org/10.1007/BF01019579.

[62] H.J.W. Lenderink, M.V.D. Linden, J.H.W. De Wit, Corrosion of aluminium in acidic and neutral solutions, Electrochim. Acta 38 (1993) 1989-1992, http:// dx.doi.org/10.1016/0013-4686(93)80329-X.

[63] S.E. Frers, M.M. Stefenel, C. Mayer, T. Chierchie, AC-Impedance measurements on aluminium in chloride containing solutions and below the pitting potential, J. Appl. Electrochem. 20 (1990) 996-999, http://dx.doi.org/10.1007/ BF01019578.

[64] R. Krishnakumar, Z. Szklarska-Smialowska, Optical and impedance characteristics of passive films on pure aluminium, Mater. Sci. Forum 111 (1992) 565-580.
[65] R. De Levie, Fractals and rough electrodes, J. Electroanal. Chem. 281 (1990) 1-21, http://dx.doi.org/10.1016/0022-0728(90)87025-F.

[66] A. Conde, J.J. De Damborenea, Electrochemical impedance spectroscopy for studying the degradation of enamel coatings, Corros. Sci. 44 (2002) 1555-1567, http://dx.doi.org/10.1016/S0010-938X(01)00149-4.

[67] B. Jayaraj, V.H. Desai, C.K. Lee, Y.H. Sohn, Electrochemical impedance spectroscopy of porous $\mathrm{ZrO}_{2}-8 \mathrm{wt} . \% \mathrm{Y} 2 \mathrm{O} 3$ and thermally grown oxide on nickel aluminide, Mater. Sci. Eng. A 372 (2004) 278-286, http://dx.doi.org/10. 1016/j.msea.2004.01.005.

[68] M. Cai, Oxidation of zinc in alkaline solutions studied by electrochemical impedance spectroscopy, J. Electrochem. Soc. 143 (1996) 3895, http://dx.doi. org/10.1149/1.1837313.

[69] J.-B. Jorcin, N. Pébère, B. Tribollet, CPE analysis by local electrochemical impedance spectroscopy, Electrochim. Acta 51 (2006) 1473-1479, http://dx. doi.org/10.1016/j.electacta.2005.02.128.

[70] B. Hirschorn, M.E. Orazem, B. Tribollet, V. Vivier, I. Frateur, M. Musiani, Determination of effective capacitance and film thickness from constant-phase-element parameters, Electrochim. Acta 55 (2010) 6218-6227, http://dx.doi.org/10.1016/j.electacta.2009.10.065.

[71] C. Liu, Q. Bi, A. Leyland, A. Matthews, An electrochemical impedance spectroscopy study of the corrosion behaviour of PVD coated steels in $0.5 \mathrm{~N}$ $\mathrm{NaCl}$ aqueous solution: part II. EIS interpretation of corrosion behaviour, Corros. Sci. 45 (2003) 1257-1273, http://dx.doi.org/10.1016/S0010938X(02)00214-7.

[72] J.R. MacDonald, Impedance Spectroscopy - Emphasizing Solid Materials and Systems, John Wiley \& Sons, New York, 1987, pp. 91 (ISBN:0-471-83122-0).

[73] J.N. Balaraju, S.K. Seshadri, Synthesis and corrosion behavior of electroless Ni-P-Si3N4 composite coatings, J. Mater. Sci. Lett. 17 (1998) 1297-1299, http://dx.doi.org/10.1023/A:1006528229614.

[74] S.K. Rajiv, E.P. Seshadri, Polarization and galvanic studies of cobalt-titania cermets in corrosive environments, Plat. Surf. Finish. 79 (1992) 85-88 (ISSN 0360-3164). 